\title{
11. MINERALOGICAL AND GEOCHEMICAL INVESTIGATIONS ON LATEST MIOCENE DEPOSITS IN THE TYRRHENIAN SEA (ODP LEG 107) ${ }^{1}$
}

\author{
Hervé Chamley, ${ }^{2}$ Pierre Debrabant, ${ }^{2}$ Christian Robert, ${ }^{3}$ Georges Mascle, ${ }^{4}$ Jean-Pierre Rehault, ${ }^{5}$ \\ and Jean Aprahamian ${ }^{4}$
}

\begin{abstract}
Late Miocene sediments from ODP Sites 652 and 654, drilled on the Sardinian margin in the Western Tyrrhenian Sea, are investigated through mineralogical, micromorphological, geochemical, and microgeochemical analyses. Clay associations appear to be little controlled by conditions of deposition, and largely depend on pre- and post-depositional conditions. The sedimentary series from Central Mediterranean gives very different geodynamic information, according to the sector considered. While relatively stable conditions, like those encountered in Caltanissetta Basin, Sicily, favor the mineralogical expression of warm-temperate and subarid Messinian climate, the Eastern Sardinia margin (Site 654) clay suites mainly reflect the transition from tectonically active to relaxed conditions. The series deposited at the foot of the same margin above a thinner crust (Site 652) experienced the effects of burial diagenesis, enhanced by strong geothermal gradient.
\end{abstract}

\section{MATERIAL AND METHODS}

Pre-Pliocene sediments recovered in the Western Tyrrhenian Sea during ODP Leg 107 (Kastens, Mascle, et al., 1987) have been investigated using mineralogical and geochemical analyses. Four drilling sites were considered from the upper part of the margin downward:

1. Site 654 , Hole $654 \mathrm{~A}$ is on a tilted block of the western part of the upper margin east of Sardinia $\left(40^{\circ} 34.76^{\prime} \mathrm{N}, 10^{\circ} 41.80^{\prime} \mathrm{E}\right.$; water depth $2218 \mathrm{~m}$; penetration $483.4 \mathrm{~m}$ ). Site 654 is located about $120 \mathrm{~km}$ westnorthwest of Site 652 (Fig. 1). Messinian to Tortonian deposits occur

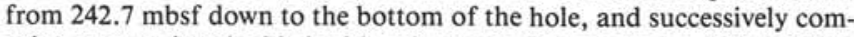
prise gypsum interbedded with calcareous clay mudstone (242.7-312.6 mbsf), dark and finely laminated organic claystone to siltstone (312.6$348.9 \mathrm{mbsf}$ ), nannofossil ooze from open to restricted marine environment (348.9-403.9 mbsf), polymictic sandstone and chalk (403.9-415.7 mbsf), reddish gravel-bearing calcareous mudstone above conglomerate, gravel, and gravelly mudstone (415.7-483.4 mbsf).

2. Site 653 , Hole 653 B is on the Sardinia margin, west of Site 652 and very close to Site 132 from DSDP, Leg $13\left(40^{\circ} 15.86^{\prime} \mathrm{N}, 11^{\circ} 26.99^{\prime} \mathrm{E}\right.$; water depth $2831 \mathrm{~m}$; penetration $262.3 \mathrm{~m}$ ). Pre-Pliocene sediments are Messinian and include various lithologies, extending on a few tens of meters: biotite- and gypsum-bearing sands, laminated gypsum, calcitecemented siltstone, nannofossil mud, marly calcareous mud, and yellow to red mud.

3. Site 652 , Hole $652 \mathrm{~A}$ is on the easternmost tilted block at the Sardinia margin-Vavilov basin boundary $\left(40^{\circ} 21.30^{\prime} \mathrm{N}, 12^{\circ} 8.59^{\prime} \mathrm{E}\right.$; water depth $3471 \mathrm{~m}$; penetration $721.1 \mathrm{~m}$; Fig. 1). Late Miocene sediments extend from 188.2 mbsf downward, and comprise more than half a kilometer of nonfossiliferous, sulfate-bearing, calcareous sandy mud and mudstone, interbedded with minor chemical sediments. Datation arguments (paleomagnetism) suggest the whole Pre-Pliocene series is Messinian in age (Channell et al., this volume).

4. Site 656 , Holes $656 \mathrm{~A}$ and $656 \mathrm{~B}$ are on the lowermost Sardinia margin, border of Vavilov basin south of Site $652\left(40^{\circ} 11.06^{\prime} \mathrm{N}\right.$, $12^{\circ} 11.03^{\prime} \mathrm{E}$; water depth $3606 \mathrm{~m}$, penetration 236.4 and $121.8 \mathrm{~m}$ ). PrePliocene sediments, possibly Messinian in age, consist of dark grey, bar-

\footnotetext{
${ }^{1}$ Kastens, K. A., Mascle, J., et al., 1990. Proc. ODP, Sci. Results, 107: College Station, TX (Ocean Drilling Program).

2 Sédimentologie, U.A. 719, Université de Lille I, 59655 Villeneuve d'Ascq Cedex, France.

${ }^{3}$ Géologie du Quaternaire, Faculté Sciences Luminy, 13288 Marseille Cedex 9, France.

${ }^{4}$ Institut Dolomieu, Université Grenoble I, 38031 Grenoble Cedex, France.

${ }^{5}$ Géodynamique Marine, Université Paris VI, 06230 Villefranche-sur-Mer, France.
}

ren calcareous dolomitic mudstone and of matrix-supported conglomerate.

Most investigations have been performed on samples from Sites 652 (140 samples) and 654 (45 samples). Sites 653 (7 samples) and 656 (4 samples) are only considered for comparison. Methods comprise X-ray diffraction on the clay fraction $(<2 \mu \mathrm{m})$ of all samples, and other techniques on selected samples (about 25 per technique): X-ray diffraction on bulk rock, transmission electron microscopy, microprobe analyses of elemental clay particles, and measurements of boron contents. The techniques used are mainly those described by Chamley et al. $(1983,1985)$ and Holtzapffel (1985); the quantitative error is about $\pm 5 \%$. In addition, measurements of the boron content were made on 19 samples, by neutron capture prompt gamma-ray activation analysis, according to the method described by Vittoz et al. (1987).

The following measurements and ratios were made from X-ray diffraction diagrams obtained from oriented pastes of less than $2 \mu \mathrm{m}$ decarbonated particles:

1. Illite crystallinity (cryst. I): width of $10 \AA$ peak at mid-height, glycolated sample (mm).

2. Smectite/illite (Sm/I): 17/10 $\AA$ height ratio, glycolated sample.

3. Chlorite/illite $(\mathrm{C} / \mathrm{I}): 4.7 / 5.0 \AA$ height ratio, air-dried sample.

4. Kaolinite/chlorite $(\mathrm{K} / \mathrm{C}): 3.57 / 3.54 \AA$ height ratio, air-dried sample.

5. Illite-vermiculite mixed-layers/illite: $12 / 10 \AA$ height ratio, glycolated sample.

6. Fe-chlorite/Mg-chlorite (indicative): ratio of $14 \AA$ peak heights after heating/after ethylene-glycolation.

\section{MAJOR MINERALOGICAL SIMILARITIES BETWEEN ODP SITES}

Holes $654 \mathrm{~A}$ and $652 \mathrm{~A}$ display diversified clay-mineral assemblages (Fig. 1) including chlorite, illite, various mixed-layers (10-

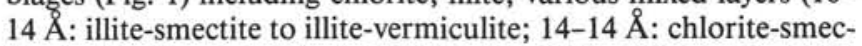
tite to chlorite-vermiculite), smectite, kaolinite, palygorskite, with associated quartz, feldspar, and goethite. The same diversity characterizes Sites 653 and 656. Previous studies have shown the following major origins for late Cenozoic clay minerals in the Western Mediterranean domain (Chamley et al., 1978; Chamley and Robert, 1980): illite and chlorite eroded from crystalline and metamorphic rocks; irregular mixed-layers reworked from moderate weathering processes; kaolinite inherited from soils developed under warm-temperate and humid conditions; smectite removed from continental soils and Tertiary sedimentary 
HOLE 654A
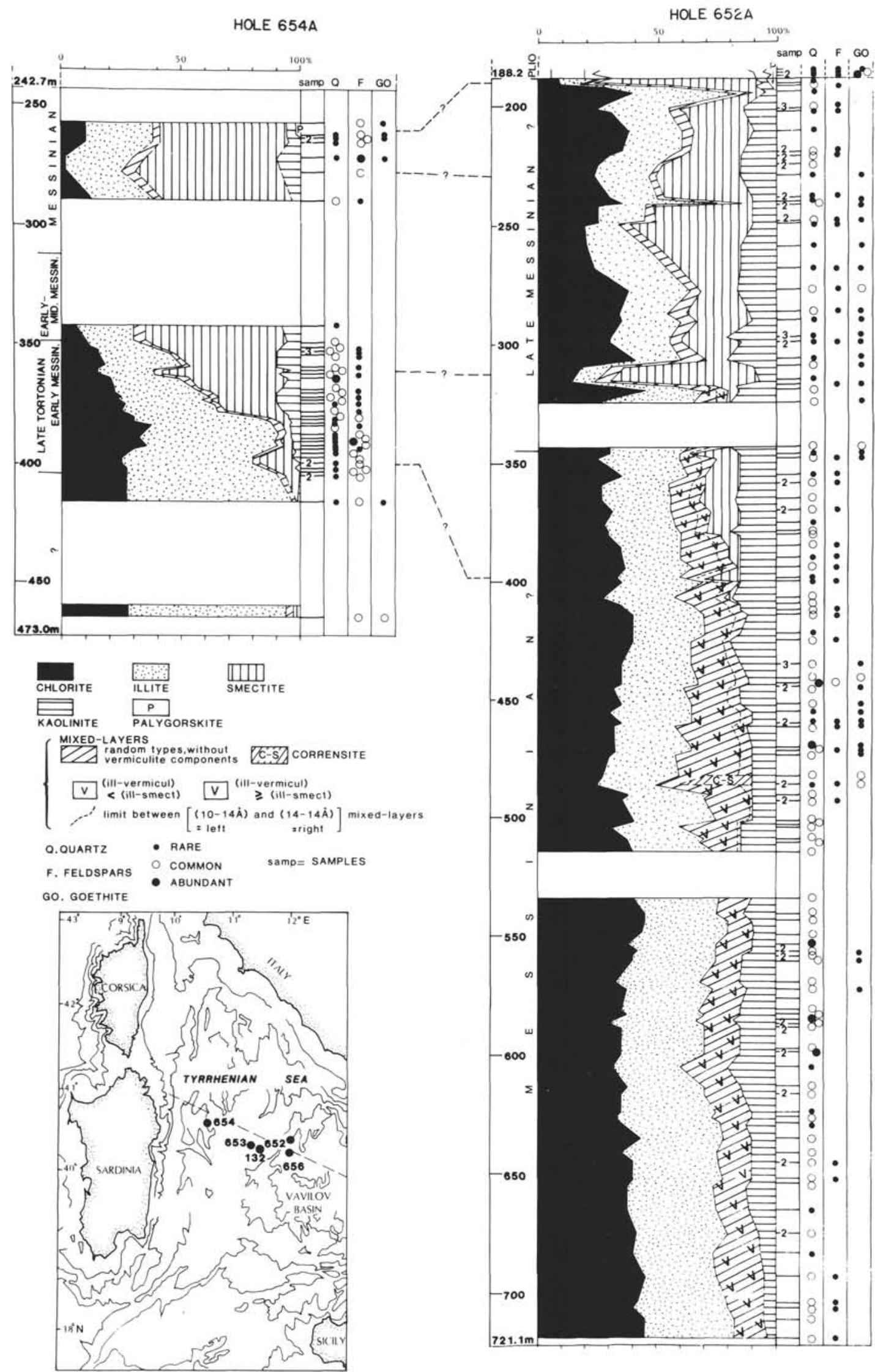

Figure 1. Holes 654A and 652A. Clay mineralogy of uppermost Miocene sediments. Data gaps result from very poor sediment recovery. Stratigraphic correlations of both sites are only indicative (dotted lines with question marks) and do not correlate to available paleomagnetic data. 
rocks; palygorskite derived from calcareous pedologic crusts or from Paleogene chemical sediments. Late Cenozoic clay minerals therefore mostly reflect detrital sources located in various peri-Mediterranean rocks and soils.

Illite, chlorite, and smectite are the most abundant minerals, the two former species being present throughout the sedimentary columns. Kaolinite and mixed-layers are subordinate, palygorskite is only locally present. Quartz is omnipresent and often abundant, while feldspar and goethite occur more locally. In both Holes $654 \mathrm{~A}$ and $652 \mathrm{~A}$, smectite is dominant in the upper part of the sections investigated, and chlorite and illite in the lower part, while palygorskite is recorded only in uppermost Messinian deposits. Important variations of clay assemblages are recorded along the sedimentary columns. They chiefly concern smectite and illite abundance. Some parallel changes exist at both drill sites, especially at the following depth intervals:

\begin{tabular}{|c|c|c|c|c|}
\hline \multirow[b]{2}{*}{$\begin{array}{l}\text { Downward } \\
\text { variation }\end{array}$} & \multicolumn{2}{|r|}{ Site 654} & \multicolumn{2}{|c|}{ Site 652} \\
\hline & $\begin{array}{c}\text { Level } \\
\text { (mbsf) }\end{array}$ & $\begin{array}{l}\text { Biostratigraphic } \\
\text { attribution }\end{array}$ & $\begin{array}{c}\text { Level } \\
\text { (mbsf) }\end{array}$ & $\begin{array}{c}\text { Biostratigraphic } \\
\text { attribution }\end{array}$ \\
\hline $\begin{array}{l}\text { Presence of } \\
\text { palygorskite }\end{array}$ & $256-260$ & late Messinian & $188-189$ & late Messinian? \\
\hline Smectite increase & 277 & late Messinian & 238 & late Messinian? \\
\hline Smectite increase & $360-362$ & $\begin{array}{l}\text { early Messinian, } \\
\text { late Tortonian }\end{array}$ & $309-315$ & late Messinian? \\
\hline Smectite increase & $397-400$ & $\begin{array}{l}\text { early Messinian, } \\
\text { late Tortonian }\end{array}$ & 398 & Messinian? \\
\hline
\end{tabular}

These mineralogical changes could result from regional events recorded at both sites, although the Sardinian margin comprises two structural units separated by a central fault (Rehault et al., 1987). If such regional causes are correct, we can propose indirect stratigraphic correlations for the nearly barren sediments of Holes 654A and 652A. Stratigraphic equivalences are tentatively suggested by question marks on Figure 1. As biostratigraphic and paleomagnetic attributions are partly questionable at both sites (Kastens, Mascle, et al., 1987; Channel et al., 1989), mineralogical correlations may constitute a useful additional tool for progressing in sediment datation. Notice that the correlations proposed from mineralogical successions do not appear to fit the paleomagnetic polarity measured at Sites 652 and 654 (Channell et al., 1989), which sets up another difficulty.

A general independence exists between lithology and clay mineralogy. This is especially clear at Site 652 , where identical or distinct lithologies may correspond to either similar or different mineralogies (Fig. 2). Each situation occurs in pre-Pliocene sediments, which points to the absence of any systematic control of lithology over mineral suites. This absence of correlation, which applies to all types of clay, mud, mudstone, siltstone, sand, calcareous mud, marl, and gypsiferous or conglomeratic sediments, is enhanced by the existence of large scale clay variations in some homogeneous deposits. For instance, the claystones sampled in Hole 652A at 193.51 and $200.51 \mathrm{mbsf}$ comprise, respectively, $5 \%$ and $35 \%$ smectite in the clay fraction, $40 \%$ and $25 \%$ chlorite, $45 \%$ and $25 \%$ illite, $5 \%$ and $15 \%$ kaolinite (Fig. 2). The clayey sands deposited at 305.96 and 309.03 mbsf contain, respectively, $10 \%$ and $55 \%$ smectite, $40 \%$ and $15 \%$ chlorite, $20 \%$ and $15 \%$ illite, $20 \%$ and $10 \%$ kaolinite. These results show that most of the clay associations are little influenced by depositional conditions, by the presence of a continental or marine environment, and by lithology-driven diagenesis. Note that the boron contents (Table 1) are indicative of normal marine to slightly hypersaline conditions (50-250 ppm), but never reach values typical of saline clays $(>1000 \mathrm{ppm}$; see Harder, 1975). The highest salinities expressed by the boron oc-
HOLE 652A

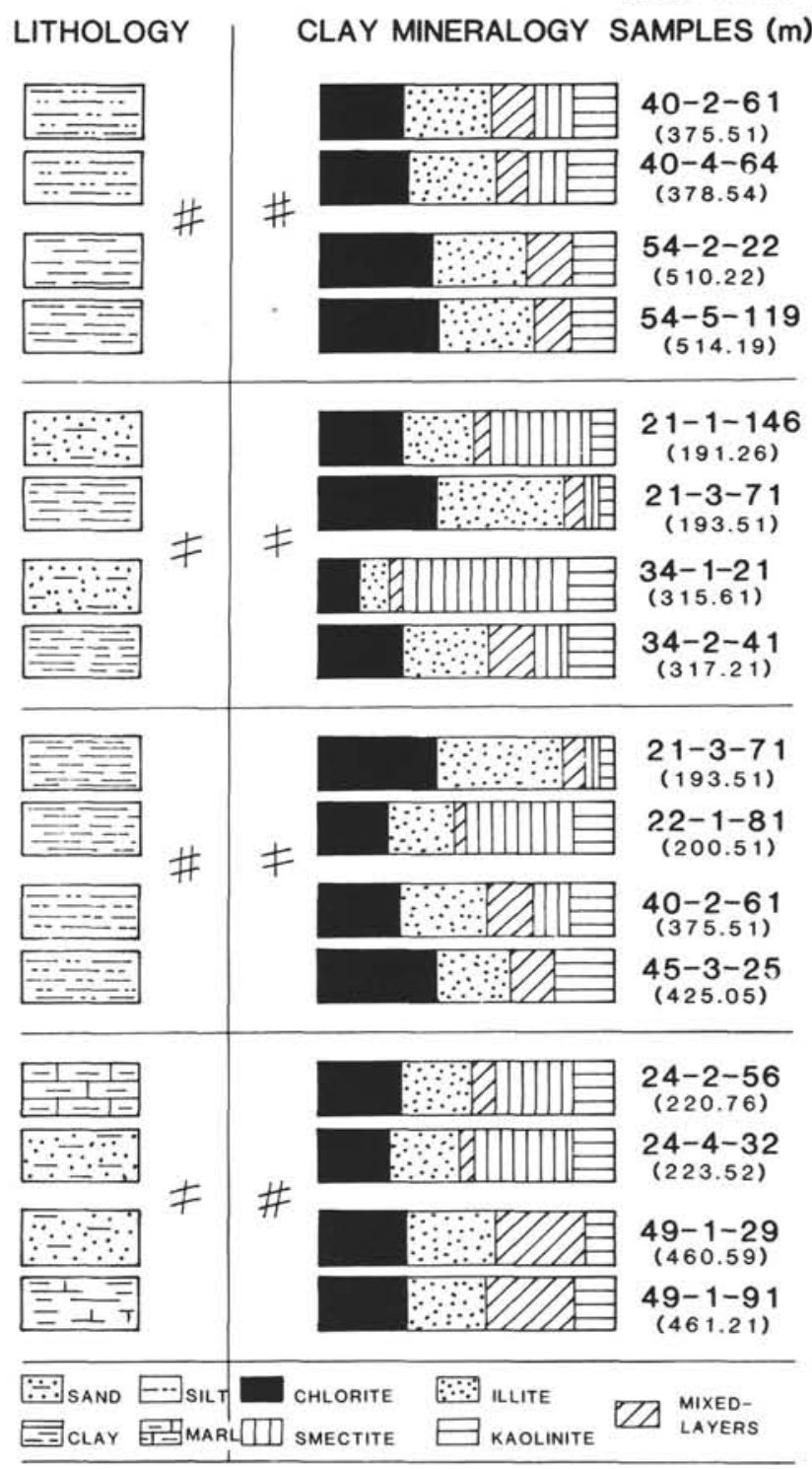

Figure 2. Hole 652A, Late Miocene. Comparison between lithology and clay mineralogy. $\neq=$ differences in lithology or mineralogy. $\#=$ similarities.

cur in the lower part of Sites 652,653 , and 654 , especially below 480 mbsf depth in Hole 652A.

The only obvious case of correspondence between lithology and clay mineralogy occurs in Hole $652 \mathrm{~A}$ at $480-485$ mbsf (Core 51, Samples 51R-2-17, 51R-4-52, 51R-4-62), where blackish organic claystones contain noticeable amounts $(20 \%-30 \%)$ of subregular to regular chlorite-smectite mixed-layers (corrensite). These corrensite-like minerals are present in sediments where interstitial waters display the highest contents of dissolved $\mathrm{Ca}, \mathrm{Mg}$, sulfates, and also highest chlorinity (Kastens, Mascle, et al., 1988). Corrensite is known to form in some evaporitic environments, as described in several Triassic series (e.g., Lucas, 1962; Geisler-Cussey, 1986). The presence at both Sites 652 and 654 of $\mathrm{Mg}$ chlorite, the content of which increases in the levels characterized by increased amounts of dolomite (Pierre and Rouchy, this vol), suggests that Messinian corrensite in the Tyrrhenian Sea results at least partly from evaporative influences (see "Characteristics of Site 652" below). 
Table 1. Distribution of boron in Leg 107 pre-Pliocene selected samples.

\begin{tabular}{lrrr}
\hline $\begin{array}{l}\text { Core, section, } \\
\text { interval }(\mathrm{cm})\end{array}$ & $\begin{array}{r}\text { Depth } \\
\text { (mbsf) }\end{array}$ & $\begin{array}{r}\text { Boron } \\
\text { (ppm) }\end{array}$ & $\begin{array}{r}\text { Error } \\
(\%)\end{array}$ \\
\hline $652 \mathrm{~A}-$ & & & \\
& & & \\
$20-4-141 / 143$ & 186.11 & 66.3 & 1.11 \\
$20-6-44 / 46$ & 188.14 & 66.3 & 1.11 \\
$21-3-146 / 148$ & 194.26 & 59.1 & 1.03 \\
$22-1-81 / 83$ & 200.51 & 109.9 & 1.34 \\
$31-3-81 / 83$ & 290.11 & 83.8 & 1.49 \\
$38-3-145 / 147$ & 358.45 & 89.6 & 1.22 \\
$40-5-97 / 99$ & 380.37 & 117.2 & 1.40 \\
$44-2-44 / 46$ & 414.04 & 131.7 & 1.49 \\
$50-2-10 / 12$ & 471.70 & 208.1 & 1.99 \\
$62-3-7 / 9$ & 588.27 & 210.0 & 2.06 \\
$71-2-55 / 55$ & 674.85 & 194.5 & 1.96 \\
& & & \\
$653 \mathrm{~B}-$ & & & \\
$25-1-105 / 107$ & 226.75 & 76.3 & 2.51 \\
$27-4-50 / 52$ & 249.90 & 254.3 & 11.71 \\
& & & \\
$654 \mathrm{~A}-$ & & & \\
& & & \\
$29-1-12 / 14$ & 261.82 & 85.5 & 3.09 \\
$31-1-102 / 104$ & 277.32 & 68.8 & 2.09 \\
$40-4-18 / 20$ & 352.78 & 127.3 & 4.66 \\
$45-6-54 / 56$ & 404.46 & 157.6 & 5.37 \\
$52-1-33 / 36$ & 464.43 & 138.1 & 4.60 \\
\hline & & & \\
\hline
\end{tabular}

\section{MAJOR DIFFERENCES BETWEEN SITES 652 AND 654}

Despite the rough similarity noticed in the clay stratigraphy of both Holes $654 \mathrm{~A}$ and $652 \mathrm{~A}$, some significant differences appear (Figs. 1, 3, and 4). Site 654 shows specifically a strong increase of illite abundance in the lower part. Site 652 reveals the presence of noticeable amounts of vermiculitic mixed-layers that are lacking at the other site. When looking at the average mineral contents and relative abundance ratios in both sites, Hole $654 \mathrm{~A}$ appears characterized by more abundant illite, smectite, feldspars, by better crystallized illite, and by less abundant chlorite, $10-14 \AA$ mixed layers, kaolinite, and quartz, relative to Hole 652A (Figs. 3, 4). The differences between the clay compositions at both sites are fairly strong, and suggest at least partly distinct sources or distinct formation processes (Millot, 1970). The opposing behavior of smectite and illite does not correspond to differential settling processes with increased distance from possible Sardinian sources, since smectite trend is the opposite, and also in opposition with both the abundance of mixed-layers and the poor crystallinity of illite.
To make the mineralogical differences more precise, the prePliocene clay stratigraphy at both Sites 654 and 652 has been considered more carefully by dividing the general record in successive zones characterized by similar mineral associations. Seven zones have been identified for each site, from the top of Messinian series to the base of the sedimentary column (Tables 2 and 3; Fig. 5).

The four mineral groups which mainly derive from the erosion of crystalline rocks, i.e., mica-illite, chlorite, quartz, and various feldspars, present opposing trends at Sites 654 and 652 . Illite is generally more abundant, and feldspars systematically more abundant, at Site 654, while chlorite predominates systematically, and quartz usually, at Site 652 . Site 653 displays a clay mineralogy that is intermediate between those of Sites 654 and 652 , and Site 656 sediments resemble those of Site 652 . These differences, clearly expressed on both general and detailed logs (Figs. 5, 6, and 7), suggest that mineral sources differ at Sites 654 and 652 , especially when considering the wide potential distribution of small clay particles in natural environments. Different petrographic sources were probably responsible for the supply of detrital illite, chlorite, quartz, and feldspars into the young Tyrrhenian basin during the late Miocene. These minerals, together with kaolinite and irregular mixed-layers which derive from continental weathering, were certainly removed by erosion from the tilted blocks surrounding the drilling areas. Similar clay assemblages are often present in association with synrift series, as observed in the Early Cretaceous of the Cape Basin, Southeastern Atlantic Ocean (Robert, 1987).

Abundant smectite is recorded in the upper part of Sites 652, 653,654 , and 656 , where the mineral content usually reaches more than $60 \%$ of the clay fraction (e.g., Figs. 5, 6). Smectite particles have fleecy outlines on transmission electron micrographs (Pl. 1-1, -2; Pl. 2-1, -2), which resemble the shape of smectites commonly formed in continental soils under warm climate and strong seasonal precipitation. Microprobe analyses show that smectites belong to the group of $\mathrm{Al}-\mathrm{Fe}$ beidellites (Table 4). Their chemical composition is fairly stable at Site 654; at Site 652 , the silicon content tends to increase and the iron content to decrease in late Messinian smectites. These minerals are not related to any specific Messinian environments, such as carbonate, diatomaceous, saline, or volcanogenic environments (Chamley and Robert, 1980). Al-Fe beidellites develop mainly in soils from warm and subarid areas, and occur as detrital components in most of Mediterranean and peri-Mediterranean Messinian deposits. In addition very abundant smectites characterize the Messinian deposits of the Mediterranean area only, and not the contemporaneous open sea sediments from similar latitudes (e.g., Atlantic Ocean). Messinian smectites have been interpreted as resulting mainly from the erosion of soils developed

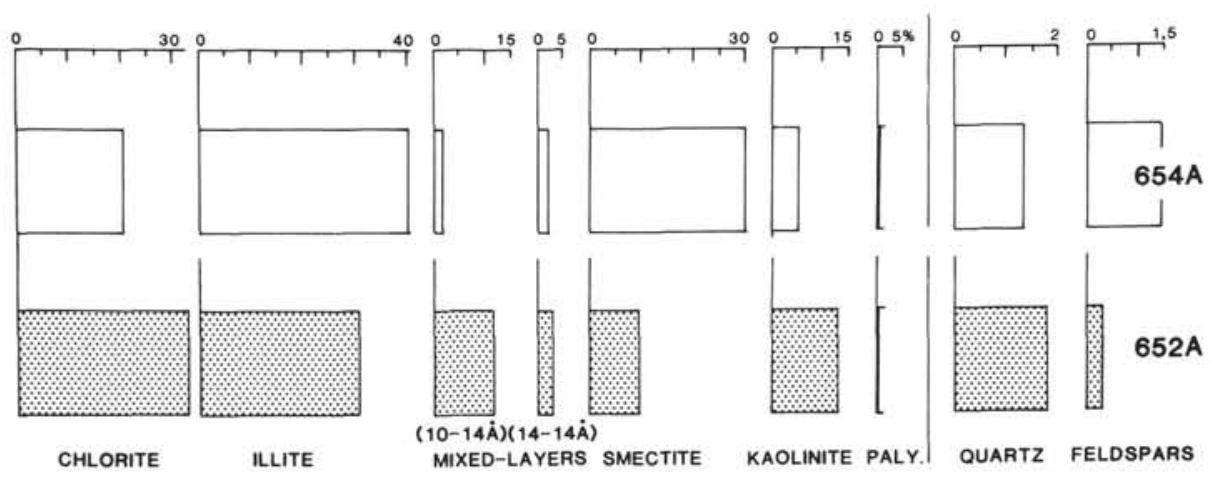

Figure 3. Average contents of clay minerals $(\%)$ and quartz and feldspar (arbitrary scale) in the $<2$ $\mu \mathrm{m}$ fraction of uppermost Miocene sediments, ODP Sites 654 and 652. 


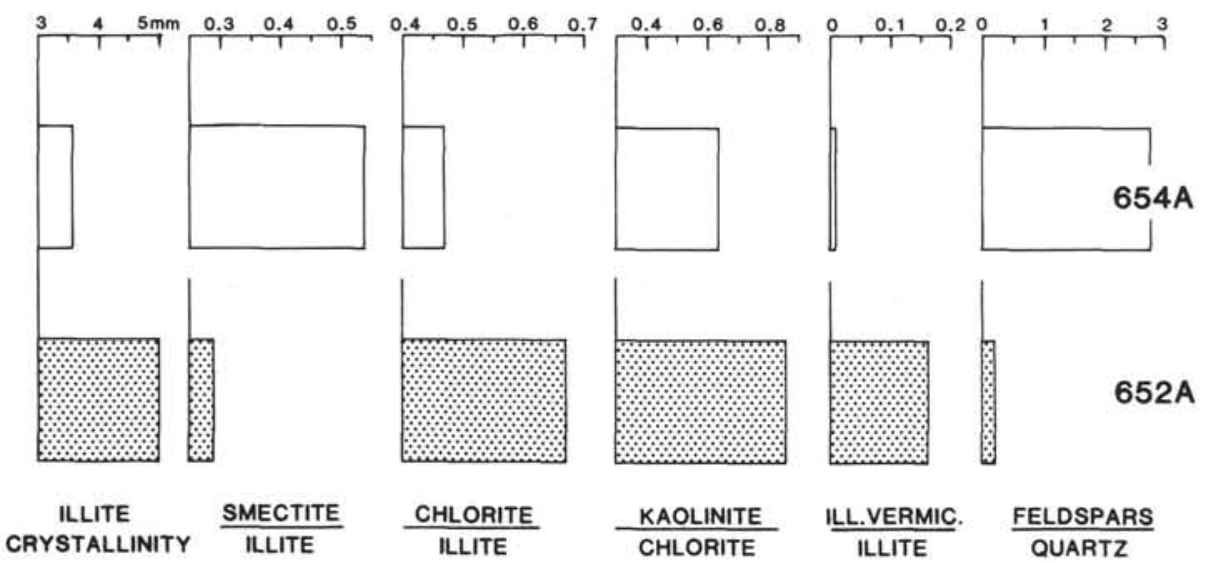

Figure 4. Clay mineralogy of uppermost Miocene deposits at Sites 654 and 652 . Comparison of some parameters and ratios.

Table 2. Clay mineral zonation of uppermost Miocene, Hole 654A.

\begin{tabular}{|c|c|c|c|c|c|c|c|c|c|c|c|c|c|c|c|}
\hline Zone & $\begin{array}{l}\text { Number of samples, } \\
\text { cores, and depth }\end{array}$ & C & I & $(10-14)$ & $(14-14)$ & $\mathrm{Sm}$ & $\mathrm{K}$ & P & Cryst. I & $\mathrm{Sm} / \mathrm{I}$ & $\mathrm{C} / \mathrm{I}$ & $\mathrm{K} / \mathrm{C}$ & $\underset{\mathrm{V}}{(10-14)}$ & F/Q & Type C \\
\hline I & $\begin{array}{c}242.7 \mathrm{mbsf} \\
\text { (7) }(28-4-15 / 31-1-102) \\
256.95-277.32 \mathrm{mbsf}\end{array}$ & 7.0 & 28.0 & 0.4 & 3.0 & 53.7 & 7.0 & 0.1 & 3.35 & 0.95 & 0.25 & 0.95 & 0.01 & 6.05 & ? \\
\hline II & $\begin{array}{c}\text { (12) }(39-2-57 / 41-4-100) \\
289.19-363.30 \mathrm{mbsf}\end{array}$ & 13.5 & 24.0 & 2.0 & 2.5 & 51.0 & 7.0 & - & 3.60 & 1.00 & 0.50 & 0.90 & 0.01 & 0.35 & 0.80 \\
\hline III & $\begin{array}{c}\text { (6) }(42-1-100 / 43-1-100) \\
348.40-378.10 \mathrm{mbsf}\end{array}$ & 23.5 & 36.0 & 2.0 & 2.0 & 27.5 & 9.0 & - & 3.40 & 0.45 & 0.55 & 0.80 & 0.01 & 0.60 & 0.80 \\
\hline IV & $\begin{array}{l}\text { (4) }(43-2-100 / 43-5-100) \\
379.60-384.10 \mathrm{mbsf}\end{array}$ & 31.0 & 53.0 & 2.0 & 2.0 & 8.0 & 4.0 & - & 3.75 & 0.15 & 0.55 & 0.60 & 0.01 & 0.80 & 0.85 \\
\hline v & $\begin{array}{c}\text { (6) }(44-1-100 / 44-6-100) \\
387.80-395.30 \mathrm{mbsf}\end{array}$ & 31.0 & 56.5 & 1.5 & 1.5 & 7.5 & 2.0 & - & 3.60 & 0.10 & 0.55 & 0.35 & 0.01 & 2.15 & 0.90 \\
\hline VI & $\begin{array}{l}\text { (6) }(45-1-100 / 45-6-54) \\
397.40-404.46 \mathrm{mbsf}\end{array}$ & 27.0 & 55.0 & 1.5 & 2.0 & 14.0 & 0.5 & - & 3.60 & 0.20 & 0.50 & 0.20 & 0.01 & 5.65 & 0.80 \\
\hline VII & $\begin{array}{r}\text { (3) }(45-6-100 / 52-1-33) \\
404.90-464.43 \mathrm{mbsf}\end{array}$ & 28.5 & 66.5 & 1.5 & 1.5 & 1.8 & 0.2 & - & 3.90 & 0.05 & 0.35 & 0.15 & 0.01 & 7.00 & 1.00 \\
\hline
\end{tabular}

Legend: $\mathrm{C}=$ chlorite; $1=$ illite; $(10-14)=10-14 \AA$ random mixed-layers; $(14-14)=14-14 \AA$ random mixed layers; $\mathrm{Sm}=$ smectite; $\mathrm{K}=$ kaolinite; $\mathrm{P}=$ palygorskite. See "Material and Methods" section for Cryst. I to Type C.

Table 3. Clay mineral zonation of uppermost Miocene, Hole 652A. For legend see Table 2.

\begin{tabular}{|c|c|c|c|c|c|c|c|c|c|c|c|c|c|c|c|}
\hline Zone & $\begin{array}{l}\text { Number of samples, } \\
\text { cores, and depth }\end{array}$ & C & I & $(10-14)$ & $(14-14)$ & $\mathrm{Sm}$ & K & $\mathrm{P}$ & Cryst. I & $\mathrm{Sm} / \mathrm{I}$ & $\mathrm{C} / \mathrm{I}$ & $\mathrm{K} / \mathrm{C}$ & $\begin{array}{c}(10-14) \\
V\end{array}$ & $\mathrm{~F} / \mathrm{Q}$ & Type C \\
\hline I & $\begin{array}{c}188.2 \mathrm{mbsf} \\
\text { (4) }(20-6-55 / 21-1-146) \\
188.25-191.26 \mathrm{mbsf}\end{array}$ & 14.0 & 18.0 & 1.5 & 3.0 & 55.0 & 7.0 & 1.5 & 4.15 & 1.50 & 0.70 & 0.70 & 0.01 & 0.50 & 0.65 \\
\hline II & $\begin{array}{c}\text { (19) }(21-3-71 / 28-1-104) \\
193.51-258.44 \text { mbsf }\end{array}$ & 25.0 & 23.0 & 3.5 & 3.0 & 33.0 & 12.5 & - & 4.20 & 1.00 & 0.70 & 0.95 & 0.01 & 0.40 & 0.90 \\
\hline III & $\begin{array}{c}\text { (10) }(29-1-37 / 34-1-31) \\
267.47-315.61 \mathrm{mbsf}\end{array}$ & 33.0 & 25.0 & 4.5 & 3.5 & 18.0 & 16.0 & - & 4.20 & 0.50 & 0.75 & 1.00 & 0.02 & 0.25 & 1.10 \\
\hline IV & $\begin{array}{c}\text { (19) }(34-2-41 / 42-4-132) \\
317.21-398.52 \text { mbsf }\end{array}$ & 31.0 & 30.0 & 9.5 & 4.5 & 9.0 & 16.0 & - & 4.45 & 0.25 & 0.60 & 1.00 & 0.10 & 0.25 & 1.00 \\
\hline V & $\begin{array}{c}(24)(42-5-56 / 52-3-27) \\
399.26-492.57 \mathrm{mbsf}\end{array}$ & 34.7 & 30.8 & 17.3 & 4.2 & - & 13.0 & - & 5.35 & 0.05 & 0.70 & 0.85 & 0.25 & 0.15 & 0.95 \\
\hline VI & $\begin{array}{c}\text { (45) }(52-3-60 / 71-2-98) \\
492.90-675.28 \mathrm{mbsf}\end{array}$ & 36.5 & 35.0 & 14.0 & 2.0 & - & 12.5 & - & 5.65 & 0.02 & 0.65 & 0.80 & 0.25 & 0.10 & 1.05 \\
\hline VII & $\begin{array}{c}\text { (6) }(72-1-131 / 75-6-129) \\
683.81-718.29 \mathrm{mbsf}\end{array}$ & 42.2 & 37.5 & 13.0 & 1.7 & - & 5.0 & - & 5.80 & 0.01 & 0.70 & 0.45 & 0.22 & 0.20 & 1.35 \\
\hline
\end{tabular}

on the Mediterranean periphery under temperate-warm and seasonally humid climate favored by the salinity crisis (Chamley and Robert, 1980). Note that abundant smectites are restricted to uppermost Messinian sediments at Sites 654 and 652. This differs from most other Mediterranean regions where this character is typical of the entire Messinian series (e.g., Caltanisetta basin, South Sicily, about $400 \mathrm{~km}$ south of Site 652 ; , Chamley et al., 1977). Specific factors should therefore be responsible for peculiarities recorded in the Western Tyrrhenian Sea, which will be discussed below.

\section{CHARACTERISTICS OF SITE 654}

In Hole 654A, a strong upward decrease of illite content between 380 and 365 mbsf (Cores $43 R$ and $42 R$ ), is balanced by a rapid increase of smectite and kaolinite (Figs. 5, 6, and 7). This variation occurs within marine sediments, it does not corre- 


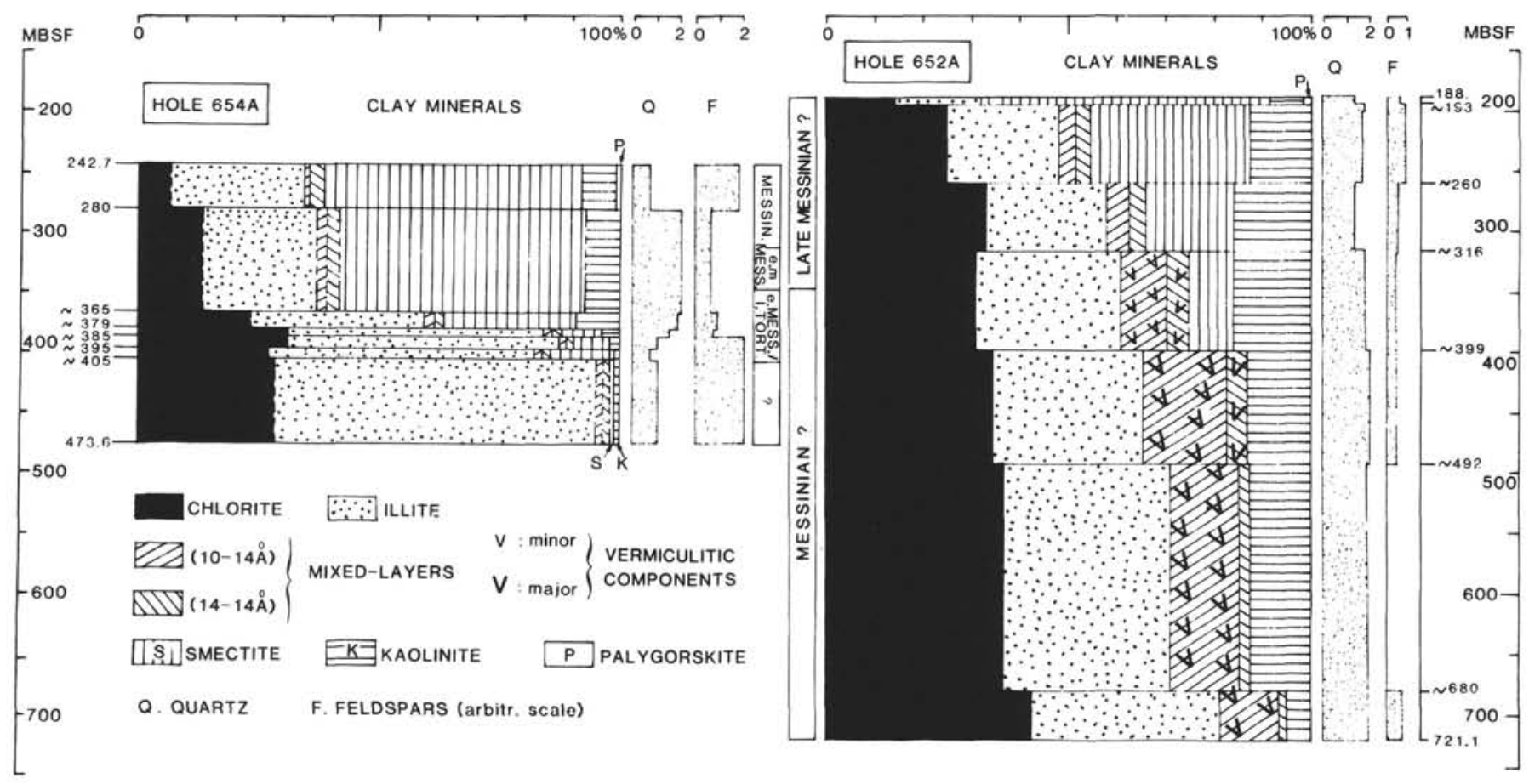

Figure 5. Clay mineral zonation of Sites 654 and 652 uppermost Miocene sediments.

spond to the passage from fresh to saline water. Chlorite and feldspar abundances diminish upward parallel to illite, while clay-sized quartz become more abundant. This strong and sudden change occurs in late Tortonian-early Messinian deposits (Fig. 5), and has no equivalence at Site 652, where sediments are supposed to be more recent. Tentative correlations proposed from clay mineral variations suggest that the event recorded at 380-365 mbsf in Hole 654A could perhaps correspond stratigraphically to the short increase of smectite identified at 315$310 \mathrm{mbsf}$ in Hole 652A (Fig. 1). Such a possibility is not confirmed so far by the sense of the magnetic polarity at both sites (Channell et al., 1989).

Illite crystallinity does not change significantly at 380-365 mbsf in Hole 654A (Fig. 7). By contrast the aspect of particles displays strong variations. In the upper part of the series, abundant fleecy smectites are associated with hexagonal kaolinite and iron oxides (goethite); illite and chlorite particles show fairly well-defined outlines but are opaque to electrons, small-sized, and slightly to strongly weathered. The uppermost Messinian levels contain palygorskite fibers (Pl. 1-1, -2). On the other hand, the sediments located below 380 mbsf contain very fresh, transparent, well-outlined, and physically broken illite-micas and chlorites, and display a wide range of grain-sizes; particle edges are very sharp and not polygonal; small-sized mixed-layers, smectite, and kaolinite constitute few additional grains (Pl. 1-3, -4). The transition between both morphologies is rapid, and marked by progressively weathered illite and chlorite, increased amounts of fleecy smectite and random mixed-layers, and more abundant hexagonal kaolinite.

Microprobe data confirm the alteration of micaceous minerals in the upper part of the section, relatively to the lower part (Table 4). Aluminous micas close to muscovite in composition occur abundantly in Samples 52R-1-33 and 47R-1-97. They become less aluminous and more siliceous and magnesian from Sample 43R-4-100 (382.10 mbsf) upward, and typical Al-micas are nearly absent in Al-Fe-beidellite-rich sediments (e.g., Samples 42R-4-100, 42R-3-100, 29R-1-12; 372.90-261.82 mbsf). Chlorites are chemically identified in the lower part of the section only, where they comprise both dioctahedral (Al) and trioctahedral (Fe-Mg) types. Al-chlorites tend to decrease upward, in altered facies, while $\mathrm{Mg}$-chlorites tend to become less abundant than Fe-chlorites.

All mineralogical, micromorphological, and microchemical characters indicate the rapid transition, from 380 to 365 mbsf in Hole $654 \mathrm{~A}$, of a mineral assemblage directly derived from the active erosion of fresh crystalline rocks to a mineral suite mainly issued from various surficial soils developed at the expense of these rocks. A similar transition has been reported in the Atlantic domain during Mesozoic times, when tectonic instability of continental margins resulting from rifting (or acceleration of spreading) was followed by the relaxation of continental borders and the development of pedogenesis (e.g., Chamley and Debrabant, 1984a). The lower series of Hole 654A, that contains abundant and fresh illite, chlorite, and feldspars, and fairly abundant quartz, points to the direct supply of terrigenous material from the tilted blocks of the Sardinia margin that were submitted to very active erosion during the early stages of the basin formation. The subsequent development of soil-derived smectite and kaolinite, the presence of moderately weathered illite and chlorite, the decreased abundance of fragile feldspars, and the presence of more resistant but highly fragmented quartz, suggest the strong diminution of tectonic activity, the progressive relaxation of Sardinia margin, and the development of pedogenic processes on exposed geological formations. Thus clay stratigraphy at Site 654 expresses during the late Tortonianearly Messinian the succession of tectonic instability, relaxation, and continental weathering on Eastern Sardinia, in relation with the formation of the Western Tyrrhenian Sea. This interpretation agrees with the passage from coarse shallow-water marine sediments to open sea hemipelagic sediments (Kastens, Mascle, et al., 1987, 1988), and with the existence of similar clay successions observed in some other instable regions of the Mediterranean range at Messinian time (e.g., Chelif basin, Algeria, and Cimmina basin, North Sicily; Chamley and Robert, 1980).

The dramatic character of the mineralogical change recorded is inconsistent with a control by the depth of burial. Diagenetic 


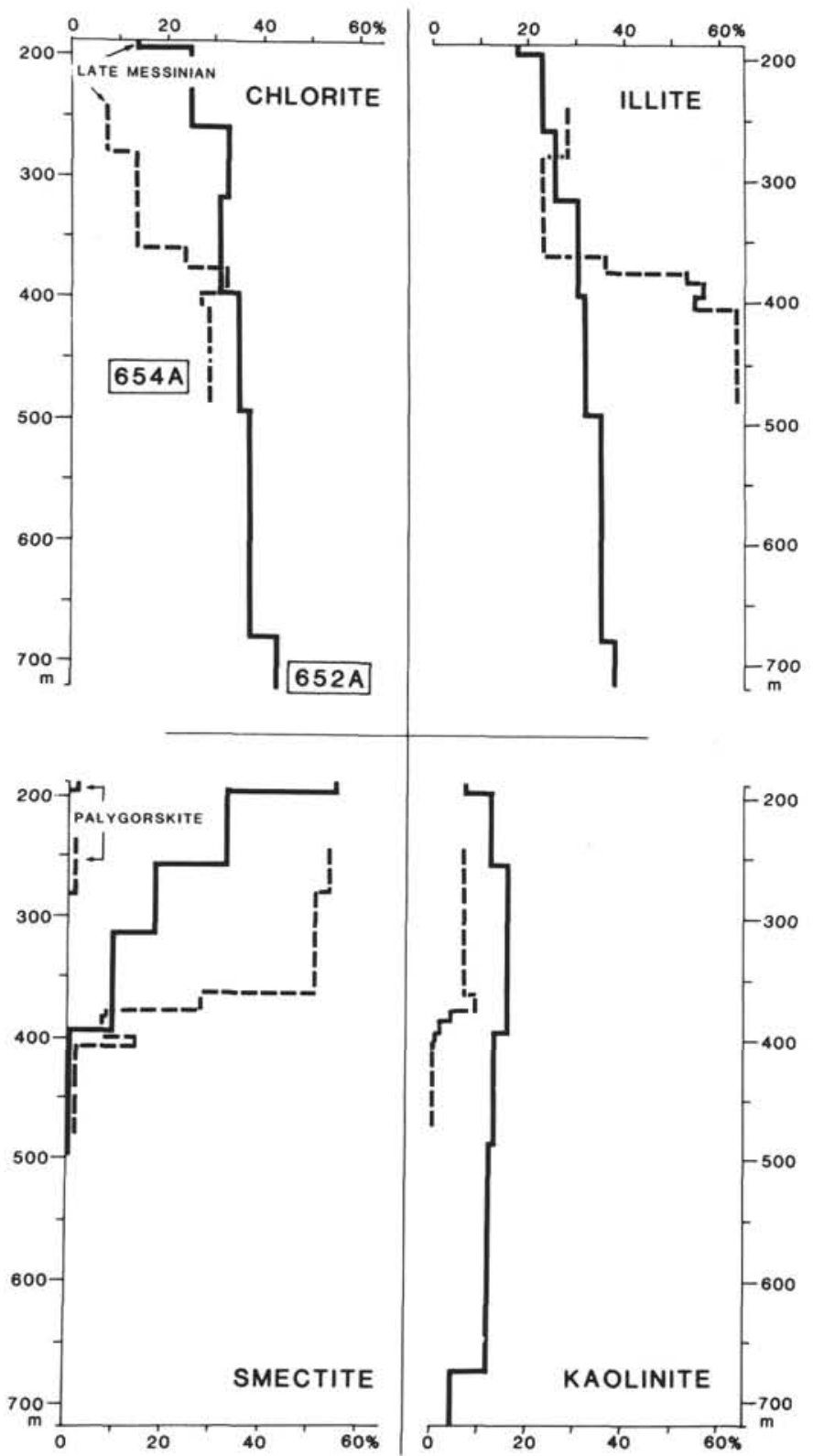

Figure 6. Zonal distribution of main clay minerals in uppermost Miocene sediments of Holes 654A and 652A. Solid line $=$ Site 652. Dashed line $=$ Site 654 .

effects could hardly have intervened on the upper margin of Sardinia, which is presently characterized by a moderate geothermal gradient $\left(4.2^{\circ} \mathrm{C} / 100 \mathrm{~m}\right)$ and by a thick underlying continental crust (Kastens, Mascle, et al., 1987).

The mineralogical and geochemical evolution recorded does not result from a climatic change, because the transition is much stronger and faster than expected from a climatic variation. In addition, the clay mineral evolution would indicate a strong cooling and diminution of weathering, which is contradicted by climatic information from Messinian series of the Mediterranean range (e.g., in Chamley and Robert, 1980). A climatic control of clay mineralogy appears only in the upper part of Site 654 Messinian sediments, from about 360 mbsf (Core 41R) upward, when abundant smectite reflects the typical temperatewarm and seasonal humidity of uppermost Miocene time in the Mediterranean range (Figs. 1, 5), especially in the northern part of the Tyrrhenian range where extension and rift activity had not yet begun (Rehault et al., 1977). Note that even in the upper part of the Messinian record, minerals derived from crystalline rocks are still more abundant than in most sections of the Mediterranean domain (e.g., Caltanisetta basin, South Sicily; Chamley et al., 1987). This points to the probable continuation of tectonic instability on the Sardinia margin during the whole Messinian, and to the combined input to the marine sedimentation of minerals derived from both the recently rejuvenated crystalline rocks and superimposed soils. Weak tectonic activity during the Messinian near Site 654 is also deduced from the local acoustic stratigraphy, and from the frequency of microfaults and slumps in Hole 654 sediments deposited before uppermost Messinian (Kastens, Mascle, et al., 1987).

The reddish sediments recovered in the lower part of Holes $654 \mathrm{~A}$ and $653 \mathrm{~B}$ mainly contain mineral suites directly derived from the physical weathering of crystalline rocks. The abundance of fresh illite, chlorite, and feldspars and the absence or scarcity of soil-borne species like kaolinite, smectite, and irregular mixed-layers preclude the possibility of significant pedogenic processes in the formation of the iron oxides responsible for the red color. Instead, metal oxides probably formed by subsequent water circulation in oxidizing conditions, favored by the frequency of coarse grain-size, and of resedimentation and shallow-water facies.

\section{CHARACTERISTICS OF SITE 652}

Despite the general correspondence observed in the clay mineralogy of Sites 654 and 652 (Fig. 1), the latter presents several specific characteristics:

1. The downward augmentation of illite abundance is very progressive instead of sharp (Figs. 5, 6), and parallels the chlorite augmentation (Figs. 6, 7).

2. Chlorite is much more abundant throughout Hole $652 \mathrm{~A}$ than at Site 654 and generally than in most Messinian sediments from the Mediterranean (e.g., Chamley et al., 1978). Chlorite content equals or exceeds illite abundance, which is quite unusual, and the chlorite tends to be more ferriferous in the lowest zone of Hole 652A (Fig. 7).

3. Mixed-layered minerals occur in fairly high amounts in Hole $652 \mathrm{~A}$ (up to $30 \%$ of the clay fraction), whereas they hardly exceed $5 \%$ at Site 654 . They are especially characterized by the presence of vermiculitic terms, whose pattern on X-ray diffractograms designates illite-vermiculite and chlorite-vermiculite complexes. Vermiculitic mixed-layers appear below $320 \mathrm{mbsf}$ in Hole $652 \mathrm{~A}$, comprise mainly illite-vermiculite, and tend to have subregular features in the lower part of the sedimentary column. Vermiculitic mixed-layers are virtually absent at Site 654 .

4. Smectite abundance tends to decrease progressively downward, with local augmentations that may be used for tentative stratigraphic correlations (see above). The mineral disappears at about 400 mbsf in sediments attributed to Messinian, whereas it is still present in small amounts at the base of Site 654 (465 mbsf) in probable Tortonian sediments (Figs. 5, 6). The disappearance of smectite correlates with an increase of vermiculitic mixed-layers (Figs. 6, 8).

5. Kaolinite abundance decreases downward in two steps, close to 400 mbsf where smectite disappears and close to 655 mbsf. The mineral exists in significant amounts $(5 \%)$ in the lower part of Hole $652 \mathrm{~A}$ (below $680 \mathrm{mbsf}$ ), while it is absent or present only in traces at the bottom of Hole 654A (464 mbsf).

6. Feldspars that are fairly common in the upper part of Hole $652 \mathrm{~A}$ are practically lacking between 492 and $680 \mathrm{mbsf}$ depth, but occur fairly abundantly in the lowermost mineralogical zone (Fig. 5). Closer to Sardinia, Hole 654A contains much more abundant feldspars, that tend to vary inversely with quartz. 


\section{H. CHAMLEY ET AL.}
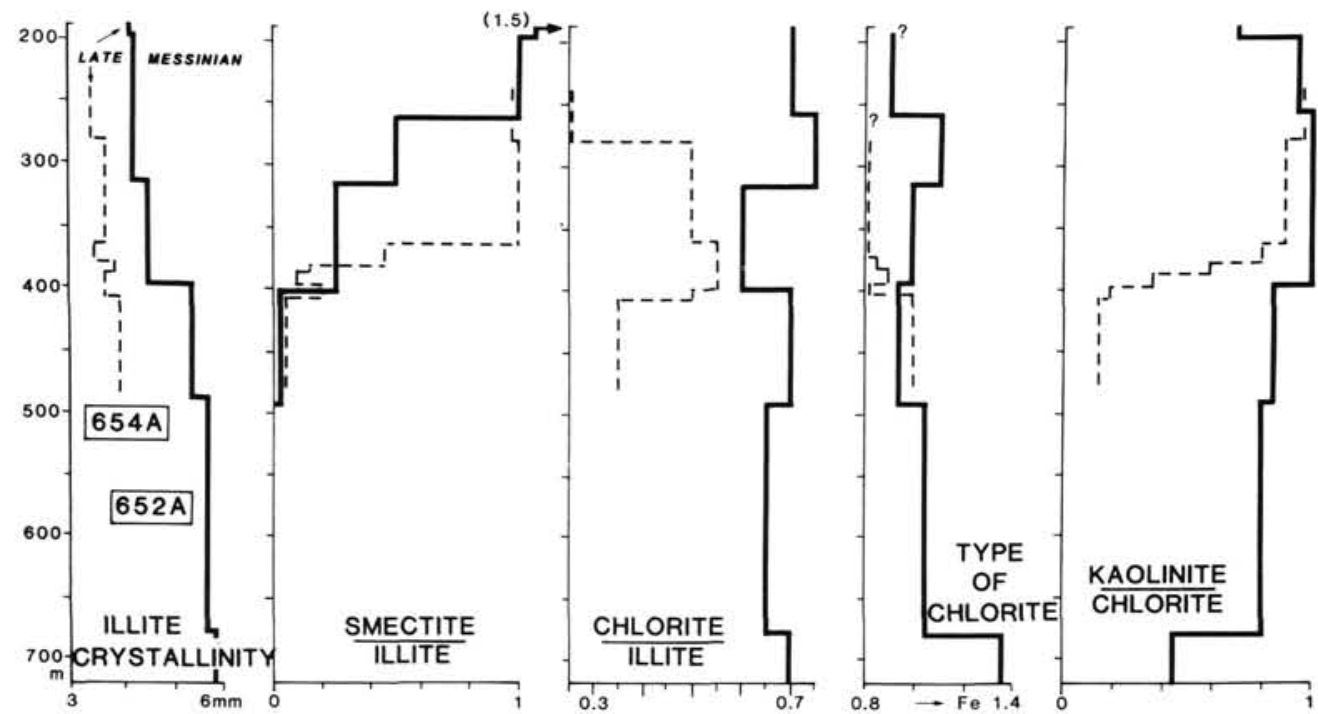

Figure 7. Zonal distribution of some clay parameters and ratios at Sites 654 and 652 . Same legend as figure 6.

When looking in more detail, the downward evolution of mixed-layered clays displays a zonation correlating with the quantitative variations of smectite, chlorite, and illite (Figs. 5, 6, and 8 ). From 188 to 316 mbsf, small amounts of illite-smectite and chlorite-smectite are identified, which resemble the whole Hole $654 \mathrm{~A}$ series. Vermiculitic mixed-layers appear at $316 \mathrm{mbsf}$ at the expense of smectite abundance, and remain in lower amounts than smectitic mixed-layers down to 400 mbsf. Vermiculitic mixedlayers predominate over smectitic mixed-layers below $400 \mathrm{mbsf}$, following the disappearance of smectite. Illite-vermiculite terms predominate over chlorite-vermiculite terms. The former occur abundantly from $316 \mathrm{mbsf}$ to the bottom of the hole, while the latter diminish strongly below about $500 \mathrm{mbsf}$ when the relative abundance of chlorite increases. A slight downward diminution of illite-vermiculite terms occurs at about $680 \mathrm{mbsf}$, together with a second diminution of chlorite-vermiculite, which corresponds to a slight augmentation of both illite (from $35 \%$ to $38 \%$ of the clay fraction) and chlorite (from $36 \%$ to $42 \%$ ).

Electron microscopic observations reveal a very peculiar zonation. Uppermost Messinian sediments contain common fleecy smectites, more or less weathered illite and chlorite, hexagonal kaolinite, and sometimes broken palygorskite and goethite (Pl. $2-1,-2$ ), which closely resemble characteristics of Hole 654A. The downward decrease of smectite corresponds to the decrease of particles with fleecy outlines, and to the appearance of very small and well-outlined particles (e.g., 358.45 mbsf, Pl. 2-3, -4). Below 400 mbsf, increased abundances of chlorite and illite correlate with the appearance of large, transparent, nearly perfectly hexagonal crystals, and with massive to elongated forms (Pl. 3-1, -2). Most hexagonal particles occur when chlorite relative abundance increases on X-ray diagrams, which suggest that these perfectly-shaped grains mainly consist of chlorite. Some micrographs show obvious growth structures (Pl. 3-3, -4). Beside these large hexagonal crystals, many very small and well-outlined crystals probably correspond to the mixed-layer structures identified on X-ray diffractograms. Those particles could be very small chlorites and illites that could give interparticle diffraction effects similar to those of true mixed-layers (Nadeau et al., 1984).

Microprobe analyses were carried out on 12 samples regularly distributed from the uppermost Messinian (Core 20R-4$141,186.11 \mathrm{mbsf}$ ) to the older sediments recovered (Core 75R-6129, 718.29 mbsf). Smectites are of a common Al-Fe beidellite type in the upper part of Hole 652A (Table 4), and do not indi- cate any volcanic influence, even at $310-315 \mathrm{mbsf}$ where they increase strongly (Fig. 1). Typical smectites tend to disappear below $320 \mathrm{mbsf}$, and are progressively replaced by particles whose chemical formulae do not belong to a single species but rather to intermediate minerals between smectite, vermiculite, and illite. This change correlates with the appearance and increase of vermiculitic mixed-layers on X-ray diagrams (Fig. 1). Illite particles display an augmentation of $\mathrm{Mg}$ and $\mathrm{Fe}$ from $186 \mathrm{mbsf}$ to 485 mbsf depth, while the total $\mathrm{Al}$ decreases (Table 4); the total charge diminishes from about 400 mbsf to $720 \mathrm{mbsf}$, while $\mathrm{Mg}$ progressively migrates from octahedral to interlayer positions. $\mathrm{Mg}$ content is maximum in Section 51R-4 where corrensite appears. Some micaceous particles analyzed in the lower part of the hole have higher values of $\mathrm{Al}$ and $\mathrm{K}$, and correspond to muscovite and rectorite (regular illite-smectite mixed-layers). Chlorites display a very broad diversity of chemical compositions, that comprise both dioctahedral and trioctahedral types, and include varied substitutions and layer charges. They are sometimes rich in titanium. Note at 485 mbsf the presence of highly magnesian chloritic particles, that correlate with the presence of corrensite on X-ray diagrams, and with the relative abundance of dissolved $\mathrm{Mg}, \mathrm{Ca}, \mathrm{Cl}$, and $\mathrm{S}$ in the interstitial water.

Site 652A mineralogy and geochemistry typically suggest the existence of diagenetic effects linked to depth of burial. The downward decrease of smectite followed by a decrease of kaolinite, the correlative development of mixed-layer minerals that become less expandable with depth, the increase of chlorite and illite, the growth of new particles with polygonal outlines, and the chemical stabilization of some clay minerals together suggest the effect of high pressure and temperature, that have been extensively described in various other regions (e.g., Hower et al., 1976; Kisch, 1983; Nadeau et al., 1984). Especially the successive steps of "mixed-layer" evolution appear to represent successive stages of mineral transformation. The appearance of vermiculitic terms at about 316 mbsf, coeval with the decrease of smectite, suggests the transition from expandable minerals to nonexpandable structures. The decrease at $500 \mathrm{mbsf}$ of chloritevermiculite, correlative to the increase of chlorite, suggests the transition from the random structure to a specific mineral, and the same evolution applies at about 680 mbsf to both illite-vermiculite and illite.

Clay changes controlled by burial effects usually do not occur in sedimentary series thinner than 2-3 km (e.g., Kisch, 1983). 
Table 4. Clay mineral chemistry, from microprobe investigations (\%).

\begin{tabular}{|c|c|c|c|c|c|c|c|c|c|}
\hline Samples & ${ }^{a} \mathrm{~N}$ & $\mathrm{SiO}_{2}$ & $\mathrm{Al}_{2} \mathrm{O}_{3}$ & $\mathrm{MgO}$ & $\mathrm{Fe}_{2} \mathrm{O}_{3}$ & $\mathrm{TiO}_{2}$ & $\mathrm{~K}_{2} \mathrm{O}$ & $\mathrm{Na}_{2} \mathrm{O}$ & $\mathrm{CaO}$ \\
\hline \multicolumn{10}{|c|}{ Illites } \\
\hline \multicolumn{10}{|c|}{ Hole $652 \mathrm{~A}$} \\
\hline $20-4-141 / 143$ & 7 & 46.91 & 31.48 & 2.50 & 6.29 & 0.31 & 8.00 & 2.22 & 1.71 \\
\hline $26-1-68 / 70$ & 8 & 49.66 & 31.33 & 4.00 & 6.72 & 0.22 & 6.99 & 0.57 & 0.39 \\
\hline $34-1-21 / 22$ & 7 & 53.00 & 28.27 & 3.46 & 6.97 & 0.31 & 6.24 & 0.77 & 0.77 \\
\hline $34-2-41 / 46$ & 18 & 50.98 & 27.40 & 3.33 & 6.82 & 1.29 & 8.08 & 1.06 & 0.71 \\
\hline $37-1-29 / 32$ & 20 & 51.35 & 27.40 & 3.56 & 7.84 & 0.50 & 6.09 & 1.88 & 0.95 \\
\hline $45-2-56 / 60$ & 20 & 50.28 & 26.54 & 3.57 & 6.98 & 1.41 & 8.12 & 1.09 & 1.47 \\
\hline $49 \mathrm{R}-1-29 / 31$ & 14 & 50.25 & 25.19 & 4.75 & 9.35 & 0.82 & 7.38 & 1.08 & 0.80 \\
\hline $51 \mathrm{R}-4-52 / 54$ & 18 & 50.07 & 26.30 & 7.55 & 8.77 & 0.39 & 5.25 & 0.88 & 0.68 \\
\hline $59 \mathrm{R}-1-44 / 46$ & 16 & 50.01 & 29.30 & 3.34 & 9.14 & 0.43 & 6.41 & 0.75 & 0.35 \\
\hline$b_{\text {musc. }}$ & 2 & 45.98 & 36.52 & 1.75 & 3.29 & 0.27 & 10.05 & 1.78 & 0.02 \\
\hline $68-2-55 / 58$ & 12 & 53.96 & 27.70 & 3.81 & 5.77 & 0.49 & 6.69 & 1.03 & 0.56 \\
\hline musc. & 4 & 51.72 & 35.42 & 1.64 & 1.54 & 0.09 & 8.74 & 0.64 & 0.20 \\
\hline $75-6-129 / 132$ & 18 & 51.75 & 30.51 & 3.71 & 5.49 & 0.34 & 6.78 & 1.02 & 0.41 \\
\hline musc. & 2 & 47.01 & 36.70 & 2.11 & 3.32 & 0.20 & 9.53 & 0.92 & 0.21 \\
\hline \multicolumn{10}{|c|}{ Hole $654 \mathrm{~A}$} \\
\hline $29.1-98 / 100$ & 10 & 51.42 & 27.66 & 3.42 & 9.38 & 0.28 & 6.00 & 0.62 & 0.94 \\
\hline $42-3-100 / 102$ & 14 & 51.26 & 30.90 & 3.42 & 4.20 & 0.52 & 7.75 & 1.41 & 0.56 \\
\hline $42-4-100 / 102$ & 12 & 51.16 & 29.23 & 3.22 & 5.30 & 0.41 & 9.31 & 1.09 & 0.29 \\
\hline $43-4-100 / 102$ & 20 & 51.75 & 31.23 & 3.13 & 4.50 & 0.25 & 7.67 & 1.12 & 0.37 \\
\hline $47-1-97 / 99$ & 14 & 47.89 & 33.71 & 2.33 & 4.40 & 0.84 & 9.15 & 1.53 & 0.26 \\
\hline $52-1-33 / 36$ & 24 & 46.78 & 33.31 & 2.37 & 7.20 & 0.75 & 7.38 & 1.88 & 0.21 \\
\hline
\end{tabular}

Chlorites

\begin{tabular}{|c|c|c|c|c|c|c|c|c|c|}
\hline \multicolumn{10}{|c|}{ Hole $652 \mathrm{~A}$} \\
\hline $20-4-141 / 143$ & 2 & 27.73 & 19.92 & 12.99 & 32.49 & 0.13 & 2.41 & 1.57 & 1.79 \\
\hline $21-1-29 / 31$ & 2 & 35.77 & 21.76 & 7.75 & 26.90 & 1.61 & 4.60 & 0.77 & 0.55 \\
\hline $26-1-68 / 70$ & 2 & 35.23 & 21.97 & 11.93 & 28.15 & 0.29 & 1.05 & 0.51 & 0.67 \\
\hline $34-1-21 / 22$ & 2 & 32.37 & 21.14 & 8.95 & 31.94 & 2.30 & 1.79 & 0.54 & 0.89 \\
\hline $37-1-29 / 32$ & 5 & 39.07 & 22.58 & 7.34 & 23.83 & 0.48 & 3.64 & 1.64 & 0.97 \\
\hline $42-5-56 / 60$ & 7 & 39.54 & 22.94 & 6.11 & 23.52 & 0.84 & 4.66 & 0.63 & 0.79 \\
\hline \multirow[t]{2}{*}{$49-1-29 / 31$} & 5 & 37.92 & 21.74 & 8.00 & 24.67 & 1.29 & 4.18 & 1.03 & 0.81 \\
\hline & 7 & 37.86 & 23.53 & 10.60 & 23.91 & 0.65 & 2.44 & 0.44 & 0.58 \\
\hline \multirow[t]{2}{*}{$51-4-52 / 54$} & 3 & 35.69 & 20.30 & 18.10 & 23.58 & 0.08 & 1.24 & 0.49 & 0.38 \\
\hline & 4 & 39.79 & 19.66 & 23.29 & 12.93 & 0.27 & 1.19 & 1.12 & 1.20 \\
\hline $59-1-44 / 46$ & 5 & 37.93 & 22.12 & 11.83 & 24.32 & 0.52 & 2.30 & 0.44 & 0.24 \\
\hline $68-2-55 / 58$ & 6 & 32.06 & 23.56 & 10.59 & 31.01 & 0.39 & 1.42 & 0.69 & 0.30 \\
\hline \multicolumn{10}{|c|}{ Hole $654 \mathrm{~A}$} \\
\hline $42-3-100 / 102$ & 7 & 38.58 & 23.81 & 8.82 & 23.01 & 0.21 & 3.26 & 1.31 & 0.97 \\
\hline $42-4-100 / 102$ & 6 & 34.41 & 22.54 & 9.70 & 28.95 & 0.36 & 3.08 & 0.61 & 0.33 \\
\hline $43-4-100 / 102$ & 6 & 36.71 & 23.30 & 10.35 & 25.58 & 0.05 & 2.64 & 0.72 & 0.69 \\
\hline $47-1-97 / 99$ & 9 & 34.01 & 25.64 & 9.42 & 25.79 & 0.88 & 2.70 & 1.07 & 0.32 \\
\hline $52-1-33 / 36$ & 4 & 27.27 & 21.73 & 14.84 & 33.46 & 0.53 & 0.46 & 1.19 & 0.28 \\
\hline \multicolumn{10}{|c|}{ Smectites } \\
\hline \multicolumn{10}{|c|}{ Hole $652 \mathrm{~A}$} \\
\hline $20-4-141 / 143$ & 11 & 49.62 & 19.34 & 5.06 & 13.13 & 0.32 & 4.98 & 3.51 & 3.05 \\
\hline $26-1-68 / 70$ & 8 & 54.37 & 25.20 & 4.23 & 8.85 & 0.23 & 4.31 & 1.18 & 1.09 \\
\hline $34-1-21 / 22$ & 23 & 57.99 & 21.49 & 4.13 & 7.94 & 0.72 & 5.13 & 1.08 & 1.16 \\
\hline $43-4-26 / 28$ & 8 & 49.06 & 28.25 & 5.39 & 9.61 & 0.30 & 5.46 & 1.22 & 0.72 \\
\hline \multicolumn{10}{|c|}{ Hole $654 \mathrm{~A}$} \\
\hline $29-1-98 / 100$ & 26 & 53.13 & 21.22 & 4.11 & 13.15 & 0.60 & 4.74 & 0.86 & 1.74 \\
\hline $42-3-100 / 102$ & 11 & 52.48 & 24.19 & 4.85 & 9.93 & 0.78 & 4.86 & 1.79 & 1.10 \\
\hline $42-4-100 / 102$ & 11 & 51.84 & 23.16 & 5.54 & 11.86 & 0.67 & 3.07 & 0.95 & 0.41 \\
\hline \multicolumn{10}{|c|}{ Kaolinites } \\
\hline \multicolumn{10}{|c|}{ Hole $652 \mathrm{~A}$} \\
\hline $21-1-29 / 31$ & 2 & 54.38 & 41.65 & 0.96 & 1.25 & 0.49 & 2.26 & 0.23 & 0.25 \\
\hline $26-1-68 / 70$ & 2 & 50.39 & 38.18 & 2.05 & 4.24 & 0.20 & 3.07 & 1.37 & 0.41 \\
\hline $34-1-21 / 22$ & 2 & 52.60 & 41.71 & 0.97 & 2.07 & 1.32 & 1.41 & 0.25 & 0.51 \\
\hline $34-2-41 / 46$ & 2 & 51.31 & 32.31 & 2.17 & 6.84 & 1.54 & 3.87 & 0.90 & 0.72 \\
\hline $42-5-56 / 60$ & 4 & 49.76 & 37.89 & 1.63 & 3.40 & 1.96 & 3.11 & 0.65 & 1.04 \\
\hline $49-1-29 / 31$ & 3 & 51.47 & 35.76 & 1.99 & 4.90 & 0.37 & 3.98 & 0.86 & 0.47 \\
\hline $51-4-52 / 54$ & 3 & 52.51 & 40.10 & 2.28 & 2.71 & 0.43 & 1.34 & 0.35 & 0.23 \\
\hline $59-1-44 / 46$ & 5 & 51.08 & 42.41 & 1.06 & 2.82 & 0.20 & 1.77 & 0.37 & 0.05 \\
\hline $68-2-55 / 58$ & 3 & 53.30 & 35.46 & 2.31 & 3.45 & 0.27 & 4.13 & 0.74 & 0.37 \\
\hline $75-5-129 / 132$ & 2 & 53.10 & 41.80 & 1.22 & 1.69 & 0.25 & 1.36 & 0.33 & 0.32 \\
\hline \multicolumn{10}{|c|}{ Hole $654 \mathrm{~A}$} \\
\hline $42-4-100 / 102$ & 2 & 53.14 & 33.14 & 2.50 & 3.91 & 0.22 & 4.69 & 1.95 & 0.21 \\
\hline $43-4-100 / 102$ & 3 & 51.07 & 36.53 & 1.28 & 1.61 & 0.03 & 3.66 & 4.42 & 1.37 \\
\hline $47-1-97 / 99$ & 1 & 48.27 & 39.09 & 1.32 & 1.97 & 0.20 & 4.27 & 4.68 & 0.10 \\
\hline $52-1-33 / 36$ & 1 & 47.28 & 38.15 & 1.48 & 8.09 & 0.71 & 3.01 & 1.09 & 0.11 \\
\hline
\end{tabular}

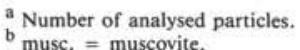

It is very unusual to identify these diagenetic effects in a series whose total thickness does not exceed $721 \mathrm{~m}$, whose age is geologically recent (late Miocene to Quaternary), and which is located on a distensive margin. Moreover Site 654, situated in the same domain at about $120 \mathrm{~km}$ to the west of Site 652 , does not reveal perceptible diagenetic effects. The remarkable case of Site 652 can be understood considering the geothermal gradient and the geodynamic context. Measurements done aboard the JOIDES Resolution evidenced very high heat flow at Site $652\left(160 \mathrm{~mW} / \mathrm{m}^{2}\right)$, with a gradient of about $14^{\circ} \mathrm{C} / 100 \mathrm{~m}$. This value is about five times higher than geothermal gradients measured on extensional margins of Atlantic type, and more than three times higher than the gradient at Site 654 . In addition, continental crust is very thin below Site 652 , located nearby the oceanic crust of Vavilov basin (Fig. 1). This differs from Site 654 which overlies a thick continental crust. The Tyrrhenian Sea constitutes a distensive back-arc basin within a general compressive environment; the thinning of the continental crust during tectonic extension causes high heat flow and the acceleration of burial diagenetic effects.

The large abundance of chlorite, relatively to illite, presents another problem. Most of argillaceous series submitted to strong burial effects contain more mica-illite than chlorite. This is the case in most diagenetic to metamorphic series (e.g., Dunoyer, 1969; Singer and Müller, 1983). In addition chlorite is abundant $(25 \%-45 \%$ of the clay fraction) nearly throughout Hole $652 \mathrm{~A}$, even in the upper part of the sedimentary column where this mineral is associated with smectite (200-320 mbsf depth). Another peculiar point is the growth of perfectly hexagonal chlorite particles in the lower part of the series (Pl. 3). This morphologic character is not usually encountered in buried sediments, except near some evaporative sediments, like early Mesozoic deposits of Mazagan Plateau, Northeast Atlantic (Chamley and Debrabant, 1984b). The preferential development of chlorite could be favored by the magnesian diagenetic environments linked to Messinian evaporitic conditions. Such an interstitial environment could favor the development of chlorite relative to illite, because magnesium is more available than potassium. The growth of euhedral hexagonal crystals could be favored by the fairly low degree of compaction of the young Messinian deposits, in comparison with the deeply buried series usually submitted to chloritization and illitization. As nondiagenetic Messinian evaporitic series do not usually display abundant chlorite and hexagonal crystal growths (e.g., Chamley et al., 1978; Chamley and Robert, 1980), we propose that Site 652 characteristics result from the combination of both an evaporitic environment and a strong thermodynamic effect.

The diagenetic influence at Site 652 could partially explain the presence of corrensite at $480-485$ mbsf (Fig. 1). This regular chlorite-smectite mixed-layer is uncommon in Messinian series devoid of noticeable diagenetic changes. Its presence at Site 652, influenced by a high geothermal gradient, suggests that pressure and temperature effects intervene dominantly in addition to highly magnesian environment (see "Major Mineralogical Similarities Between ODP Sites" above). The question therefore arises of the possibility for corrensite formation during sedimentation in evaporative environments. The example of Messinian sediments, that appear to contain this mineral only when evaporitic conditions are combined with significant geothermal effects, suggests that both saline and diagenetic conditions are needed to allow the formation of corrensite. Note that the Site 652 series remain under middle-late diagenetic influences, as shown by the absence of a downward increase of illite crystallinity (Fig. 7), and by the variable chemical composition of clay mineral species (Table 4). Such a moderate diagenetic impact allows us to propose some stratigraphic correlations with Site 654 series (see "Major Mineralogical Similarities Between ODP Sites" 
(ILLITE-SMECTITE) +

(ILLITE-VERMICULITE)
(CHLORITE-SMECTITE) +

(CHLORITE-VERMICULITE)
(ILLITE-VERMICULITE)

ILLITE
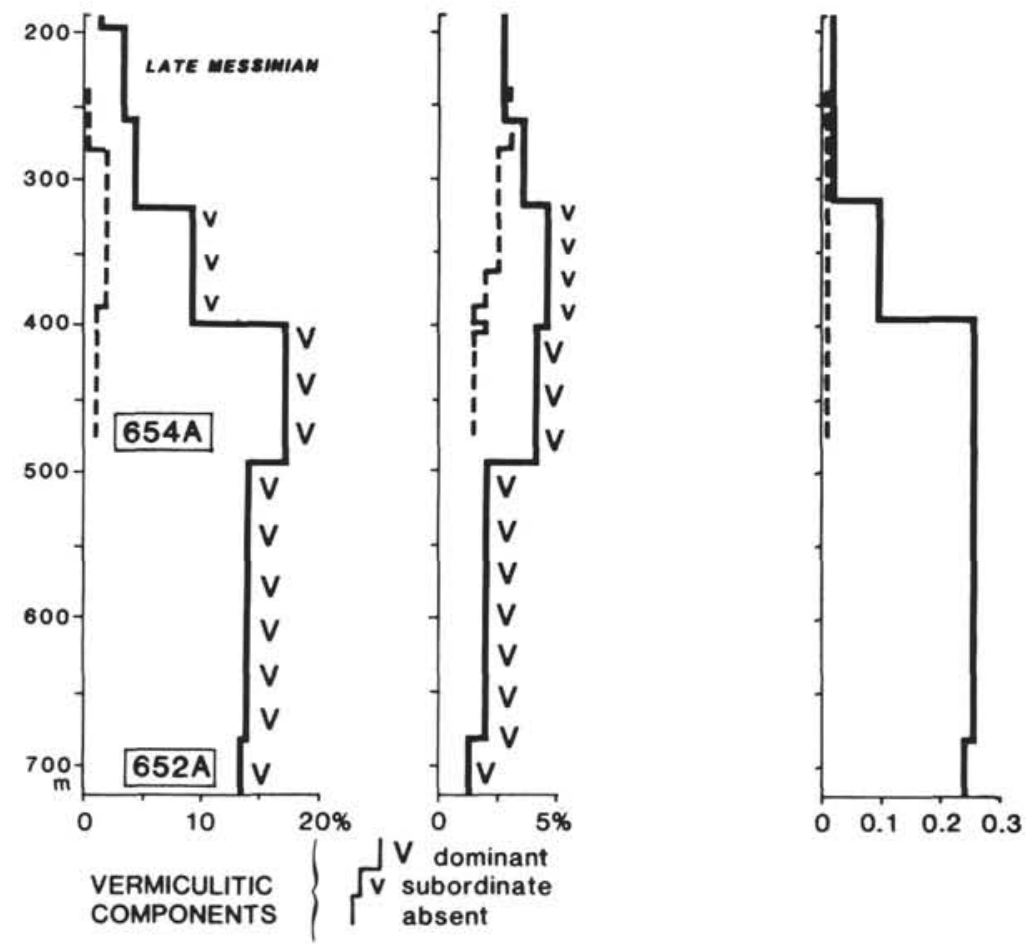

Figure 8. Zonal distribution of random mixed-layered minerals in uppermost Miocene sediments of Holes $654 \mathrm{~A}$ and $652 \mathrm{~A}$. Same legend as figure 6.

above; Fig. 1), and to envisage the passage of a tectonic to a climatic expression of clay successions in the upper series (e.g., 317 mbsf in Hole $652 \mathrm{~A}$, synchronous to the relaxation of the Sardinian margin expressed in Hole 654A at 380-365 mbsf?; see "Characteristics of Site 654" above). But the diagenetic imprint precludes any clear expression of Messinian climate at Site 652, except in the smectite-rich uppermost sediments (Core 20R).

\section{CONCLUSION}

1. During the uppermost Miocene, the Western Tyrrhenian Sea opened, determining various sedimentary deposits whose complexity was enhanced by the Messinian salinity crisis. Tortonian to Messinian sediments at Site 652 and 654 comprise coarse to fine-grained continental deposits, evaporites, calcareous oozes and chalk, and mudstone to claystone. Mineralogical, micromorphological, and geochemical investigations point to the near absence of control of clay mineralogy by lithology. Continental, brackish, and open marine environments do not result in any specific assemblages, except at 480 mbsf in Hole 652A where corrensite (regular chlorite-smectite mixed-layer) and magnesian illite correspond to reduced and $\mathrm{Mg}$-Ca-rich conditions. As a general rule, clay assemblages do not reflect peculiar depositional conditions and may be used to identify continental sources and characteristics, or post-depositional constraints. The presence of palygorskite in uppermost Messinian sediments, and the variations of smectite abundance along the sedimentary column, allow tentative stratigraphic correlations between Sites 652 and 654 , whose deposits are often devoid of fossils. Despite the general crystalline context responsible for detrital supply and displayed in the abundant mica-illite, chlorite, quartz, and feldspars, both sites display different clay mineral assemblages, which suggests different terrigenous sources and confirms petrographic observations of coarse-grained sediments.
2. At Site 654 , on the upper margin of Eastern Sardinia, a strong and rapid decrease of illite abundance occurs between 380 and 365 mbsf, in the late Tortonian-early Messinian. This important mineralogical event is associated with a decrease of chlorite and feldspar abundance, a strong increase of kaolinite and peculiarly of Al-Fe beidellite (smectite), and a less aluminous and more ferriferous-magnesian character of micas and chlorites. This remarkable change suggests the rapid transition of a tectonically unstable environment on Sardinia border, responsible for the abundant supply of rock debris to the young Tyrrhenian basin, to a fairly stable environment allowing the formation and erosion of smectitic and kaolinitic soils (Fig. 9). Such a hypothesis agrees with the tectonic influence on the Eastern Sardinia margin during the late Tortonian-early Messinian, followed by a tectonic relaxation during the rest of the Messinian. Note that the reddish deposits recovered in the lower part of Hole 654A comprise very abundant rock-derived minerals (chiefly illite, chlorite, quartz, feldspars); they do not result from chemical weathering processes, but from secondary and surficial rubefaction.

3. At Site 652 , on the easternmost part of Sardinia margin close to Vavilov basin, the mineral suites are characterized by abundant chlorite and vermiculitic mixed-layers, that progressively increase downward at the expense of smectite and kaolinite. Illite abundance follows that of chlorite, with some shifts corresponding to the successive diminution of smectite, kaolinite, chlorite-vermiculite, and illite-vermiculite. Below $400 \mathrm{mbsf}$, perfectly hexagonal and fresh chlorite particles are abundant, and are associated with very small and well-outlined particles that could correspond to illite growths. This downward evolution resembles diagenetic changes controlled by the depth of burial. The low sediment overburden, that does not exceed 721 mbsf, is balanced by a very high geothermal gradient $\left(14^{\circ} \mathrm{C} / 100 \mathrm{~m}\right.$ 


\section{SARDINIA \\ Cornaglia \\ terrace}
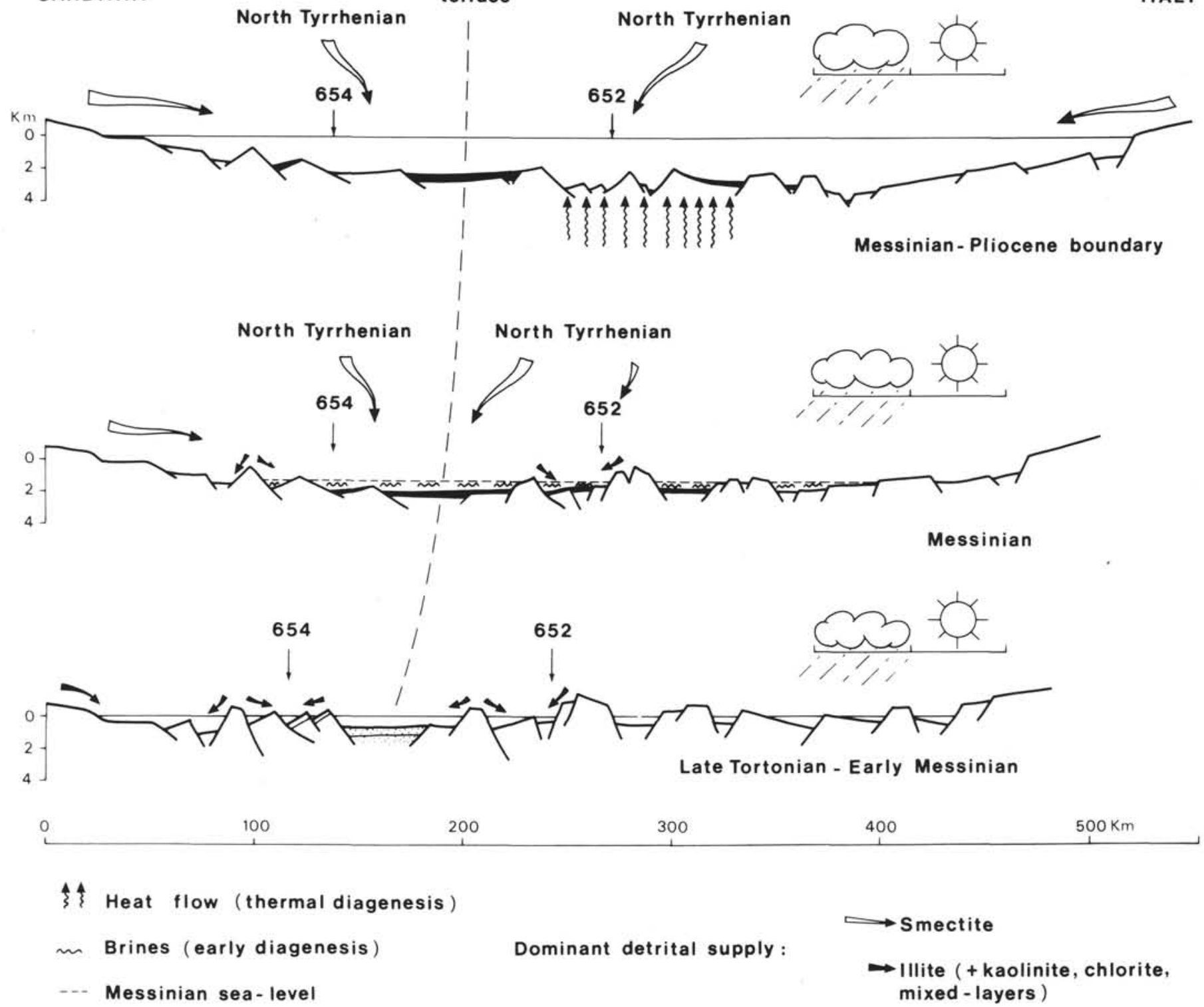

Figure 9. Geodynamical expression of uppermost Miocene clay assemblages in the Eastern Tyrrhenian Sea.

today), due to the thinning of the continental crust and to the proximity of the young oceanic crust (Fig. 9). These peculiar conditions allowed a diagenetic evolution similar to that usually recorded in more than $5 \mathrm{~km}$ thick series with normal heat flow. The low compaction due to the weak overburden could explain the development of automorphic chlorite and illite crystals through burial diagenesis. The peculiar abundance of chlorite at Site 652 relative to common diagenetic series appears to result from the combination of evaporative environment and geothermal effect. Diagenetic impact probably dominated the local formation of corrensite in confined-evaporative sediments. The absence of a downward increase of illite crystallinity, and the preservation of some detrital minerals and paleoenvironmental information, indicate that late diagenetic conditions prevailed and that the anchimetamorphic domain is not reached at the base of Hole $652 \mathrm{~A}$.

4. While Site 652 experienced strong heat flow effects and accelerated burial diagenesis, the nearby Site 654 did not experience noticeable thermodynamic influence because of its location above a thick continental crust. It mainly expresses the late Miocene tectonic activity on eastern Sardinia (Fig. 10). To the south of the Tyrrhenian Sea, in southern Sicily, the clay successions of Caltanissetta Basin display at the same time, as in most Messinian sediments of the Mediterranean range, the dominant influence of continental climate. In these regions not subject to dominant diagenetic or tectonic influences, the warm-temperate climate, marked by alternation in seasonal humidity, appears to have determined the formation of large amounts of smectite in peri-Mediterranean soils. The climate influence is generally obliterated at Site 652 and 654, and is expressed only in the uppermost Messinian sediments where tectonic and diagenetic imprints decrease. The Central Mediterranean therefore seems to combine at the same period, in a fairly small geographical area, the effects of various internal and surficial geodynamical influences, including mainly climate, tectonics, and burial diagenesis.

\section{ACKNOWLEDGMENTS}

We are greatly indebted to CNRS Grant A.S.P. ODP for financial support, and to M. Bocquet, J. Carpentier, M. Decobert, F. Dujardin, P. Récourt, and Gérard Vivier for technical procedures. This work benefited from fruitful discussions with various colleagues, namely K. Kas- 


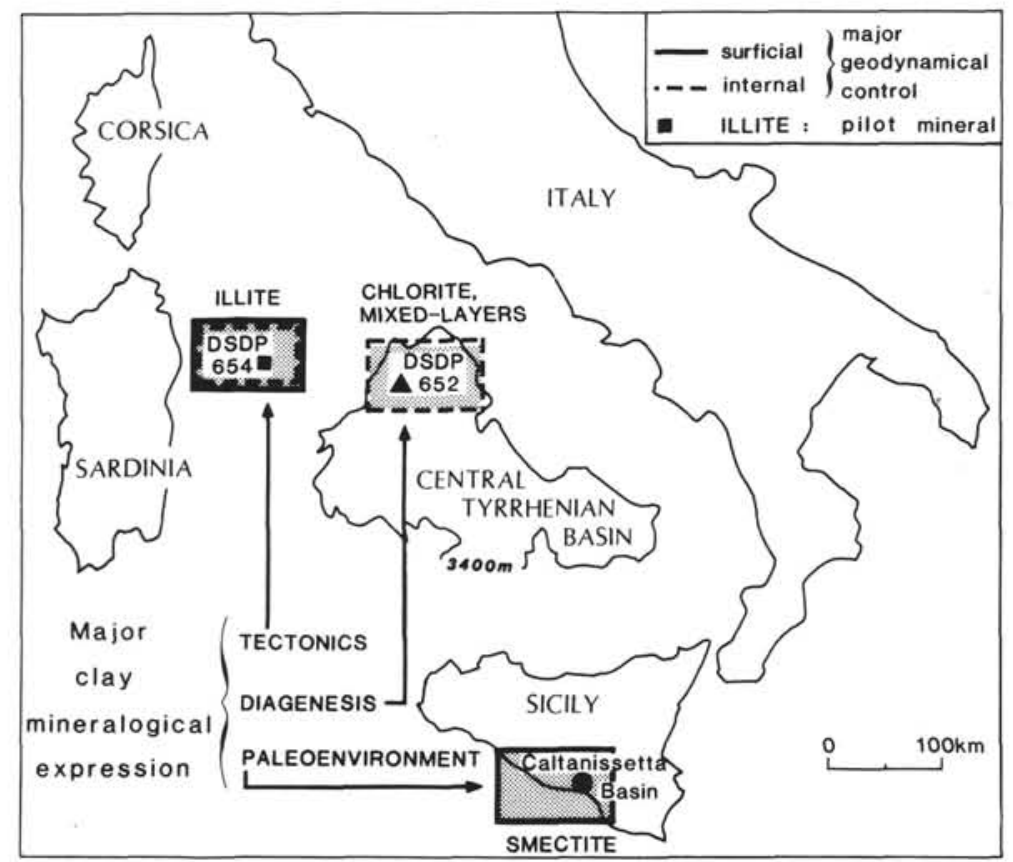

Figure 10. Major geodynamical influences on the uppermost Miocene clay sedimentation of the Central Mediterranean region. From Chamley et al. (this volume).

tens and J. Mascle, as well as from through reviews by the chief scientists and the ODP staff representative, and by two additional anonymous reviewers.

\section{REFERENCES}

Chamley, H., Coulon, H., Debrabant, P., and Holtzapffel, T., 1985. Cretaceous interactions between volcanism and sedimentation in the east Mariana Basin, from mineralogical, micromorphological, and geochemical investigations (Site 585, Deep Sea Drilling Project). In Moberly, R., Schlanger, S. O., et al., Init. Repts. DSDP, 89: Washington (U.S. Govt. Printing Office), 413-429.

Chamley, H., and Debrabant, P., 1984a. Paleoenvironmental history of the North Atlantic region from mineralogical and geochemical data. Sediment. Geol., 40:151-167.

1984b. Geochemical investigations of sediments on the Mazagan plateau, North western African Margin (Leg 79, Deep Sea Drilling Project). In Hinz, K., Winterer, E. L., et al., Init. Repts. DSDP, 79: Washington (U.S. Govt. Printing Office), 497-508.

Chamley, H., Giroud d'Argoud, G., and Robert, C., 1977. Genèse des smectites messiniennes de Sicile. Implications paléoclimatiques. Géol. Méditerr. 4:371-378.

Chamley, H., Debrabant, P., Candillier, A.-M., and Foulon, J., 1983. Clay mineralogical and inorganic geochemical stratigraphy of BlakeBahama basin since the Callovian, Site 534, Deep Sea Drilling Project Leg 76. In Sheridan, R. E., Gradstein, F. M., et al., Init. Repts. $D S D P, 76$ : Washington (U.S. Govt. Printing Office), 437-451.

Chamley, H., Dunoyer de Segonzac, G., and Mélières, F., 1978. Clay minerals in Messinian sediments of the Mediterranean area. In Hsü, K. J., Montadert, L., et al., Init. Repts. DSDP, 42A: Washington, (U.S. Govt. Printing Office), 389-395.

Chamley, H., and Robert, C., 1980. Sédimentation argileuse au Tertiaire supérieur dans le domaine méditerranéen. Géol. Méditerr., 7: 25-34.

Dunoyer de Segonzac, G., 1969. Les minéraux argileux dans la diagenèse: passage au métamorphisme. Mém. Serv. Carte géol. Als. Lorr., 29: $1-320$.

Geisler-Cussey, D., 1986. Approche sédimentologique et géochimique des mécanismes générateurs de formations évaporitiques actuelles et fossiles. Mém. Sci. Terre, 48:1-268.

Harder, H., 1975. Contribution to the geochemistry of boron in sediments. In Walker, C. T., (Ed.), Geochemistry of boron, Benchmark paper in geology, Stroudsburg, PA (Dowden, Hutchinson and Ross), 23:83-127.

Holtzapffel, T., 1985. Les minéraux argileux. Préparation. Analyse diffractométrique et détermination. Publ. Soc. géol. Nord, 12:1-136.

Hower, J., Eslinguer, Hower, M.E., and Perry, E.A., 1976. Mechanism of burial metamorphism of argillaceous sediment. Geol. Soc. Am. Bull., 87:725-737.

Kastens, K. A., Mascle, J., et al., 1987. Proc. ODP, Init. Repts., 107: College Station, TX (Ocean Drilling Program).

Kastens, K. A., Mascle, J., Auroux, C., Bonatti, E., Broglia, C., Channell, J., Curzi, P., Emeis, K. C., Glaçon, G., Hasegawa, S., Hieke, W., Mascle, G., McCoy, F., McKenzie, J., Mendelson, J., Müller, C., Rehault, J. P., Robertson, A., Sartori, R., Sprovieri, R., and Torii, M., 1988. ODP Leg 107 in the Tyrrhenian Sea: insights into passive margin and back-arc basin evolution. Geol. Soc. Am. Bull., 100:1140-1156.

Kisch, H. J., 1983. Mineralogy and petrology of burial diagenesis and incipient metamorphism in clastic rocks. In Larsen, G., and Chilingar, G.V., (Eds.), Developments in Sedimentology, New York (Elsevier), 25B:299-493.

Lucas, J., 1962. La transformation des minéraux argileux dans la sédimentation. Etude sur les argiles du Trias. Mém. Serv. géol. Als. Lorr., Strasbourg, 23:1-202.

Millot, G., 1970. The geology of clays. Berlin (Springer Verlag), 1-425.

Nadeau, P. H., Wilson, M. J., McHardy, W. J., and Tait, J. M., 1984. Interstratified clays as fundamental particles. Science, 225:923-925.

Rehault, J. P., Moussat, E., and Fabbri, A., 1987. Structural evolution of the Tyrrhenian back-arc basin. Mar. Geol., 74:123-150.

Robert, C., 1987. Clay mineral associations and structural evolution of the South Atlantic: Jurassic to Eocene. Palaeogeogr., Palaeoclimatol., Palaeoecol., 58:87-108.

Singer, A., and Müller, G., 1983. Diagenesis in argillaceous sediments. In Larsen, G., and Chilingar, G.V. (Eds.), Developments in Sedimentology, New York (Elsevier), 25B:115-212.

Vittoz, P., Oliver, R. A., Vivier, G., Kerr, S. A., and Hoyler, F., 1987. Determination of B, Sm and Gd in twenty three geological reference materials by neutron capture prompt gamma-ray activation analysis (PGAA). Geostandards Newsl., 11:43-47.

Date of initial receipt: 16 December 1987

Date of acceptance: 2 January 1989

Ms 107B-132 


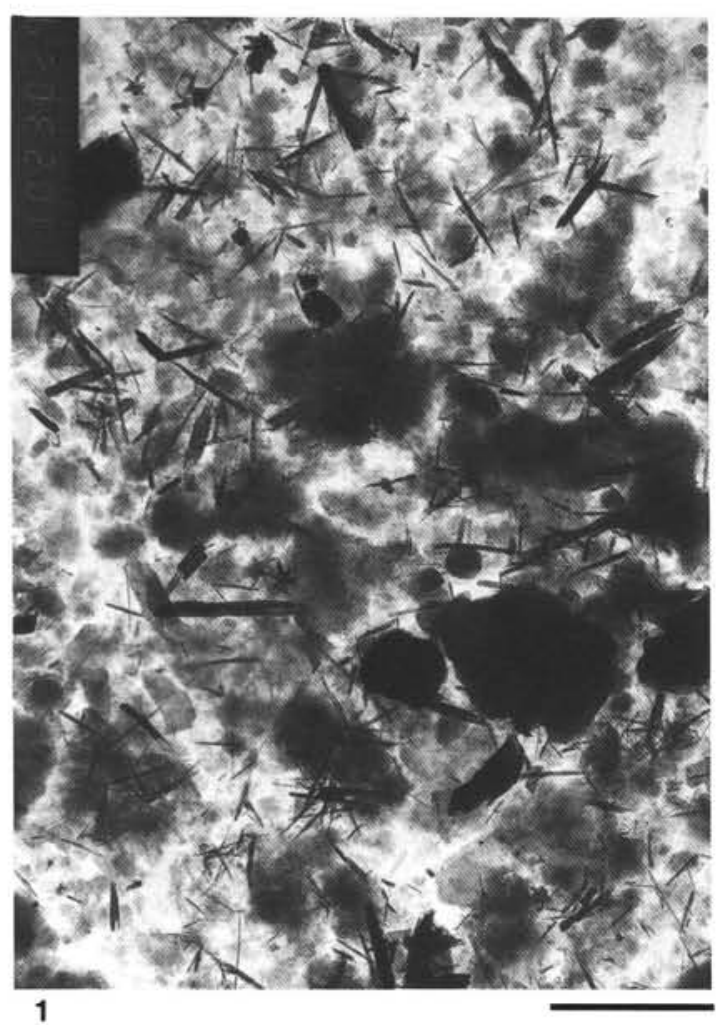

1

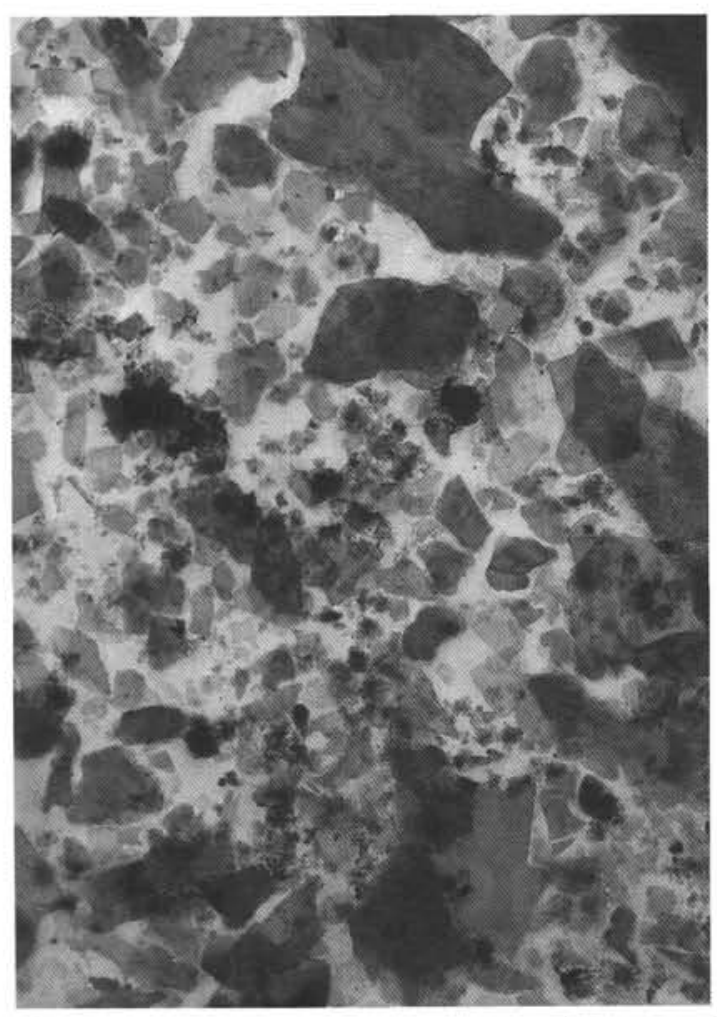

3

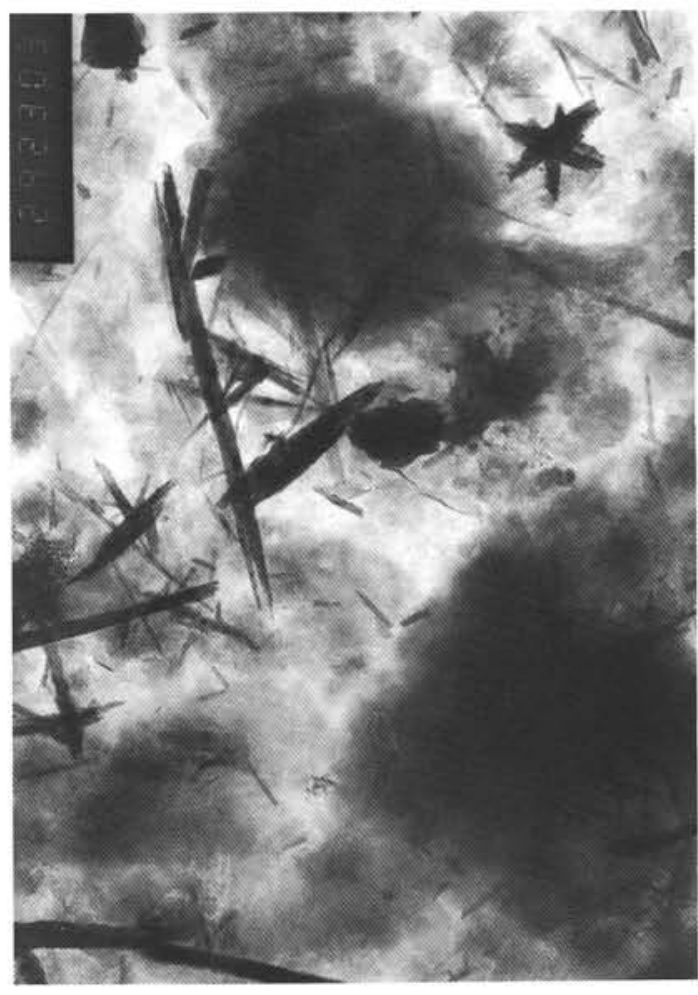

2

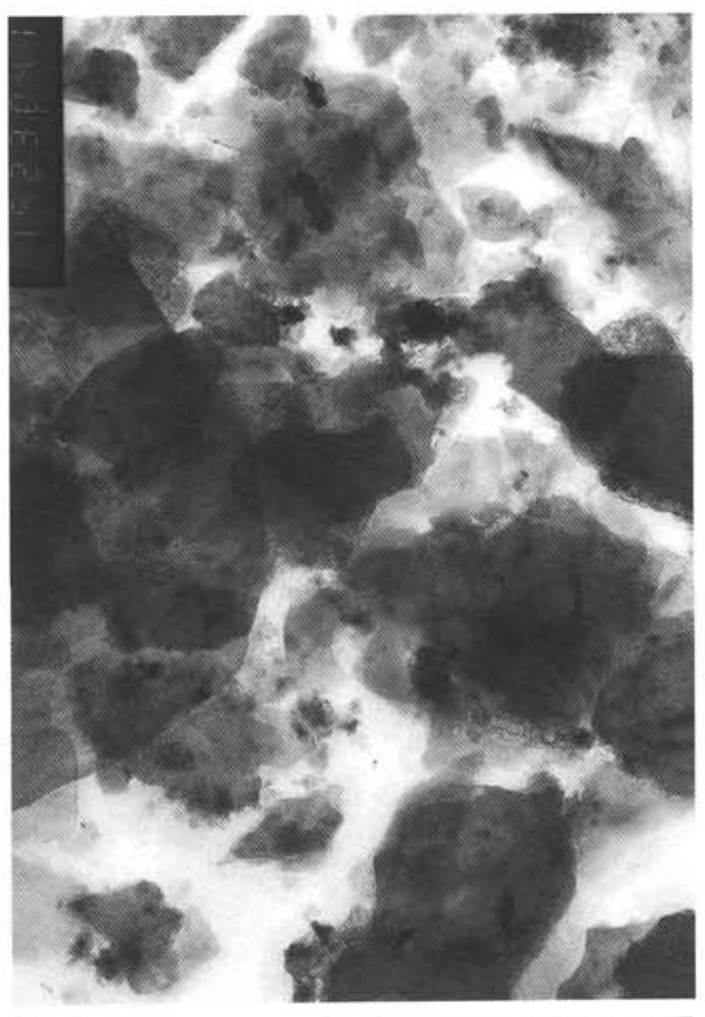

4

Plate 1. Hole 654A. Electron micrographs. Bar $=1 \mu \mathrm{m} . \quad$ 1, 2. Late Messinian. Core 31R-1-102, 277.32 mbsf. Abundant flaky smectite (60\% of clay minerals), accompanied by well-outlined nonpolygonal illite, small hexagonal kaolinite, broken palygorskite fibers, and goethite rosettes. 3, 4. Tortonian? Core 52R-1-33, 464.43 mbsf. Very abundant mica-illite and chlorite particles ( $95 \%$ of clay minerals) displaying sharp and nonhexagonal outlines, fresh aspect and various sizes. Few and small particles of fleecy mixed-layers and smectite. 

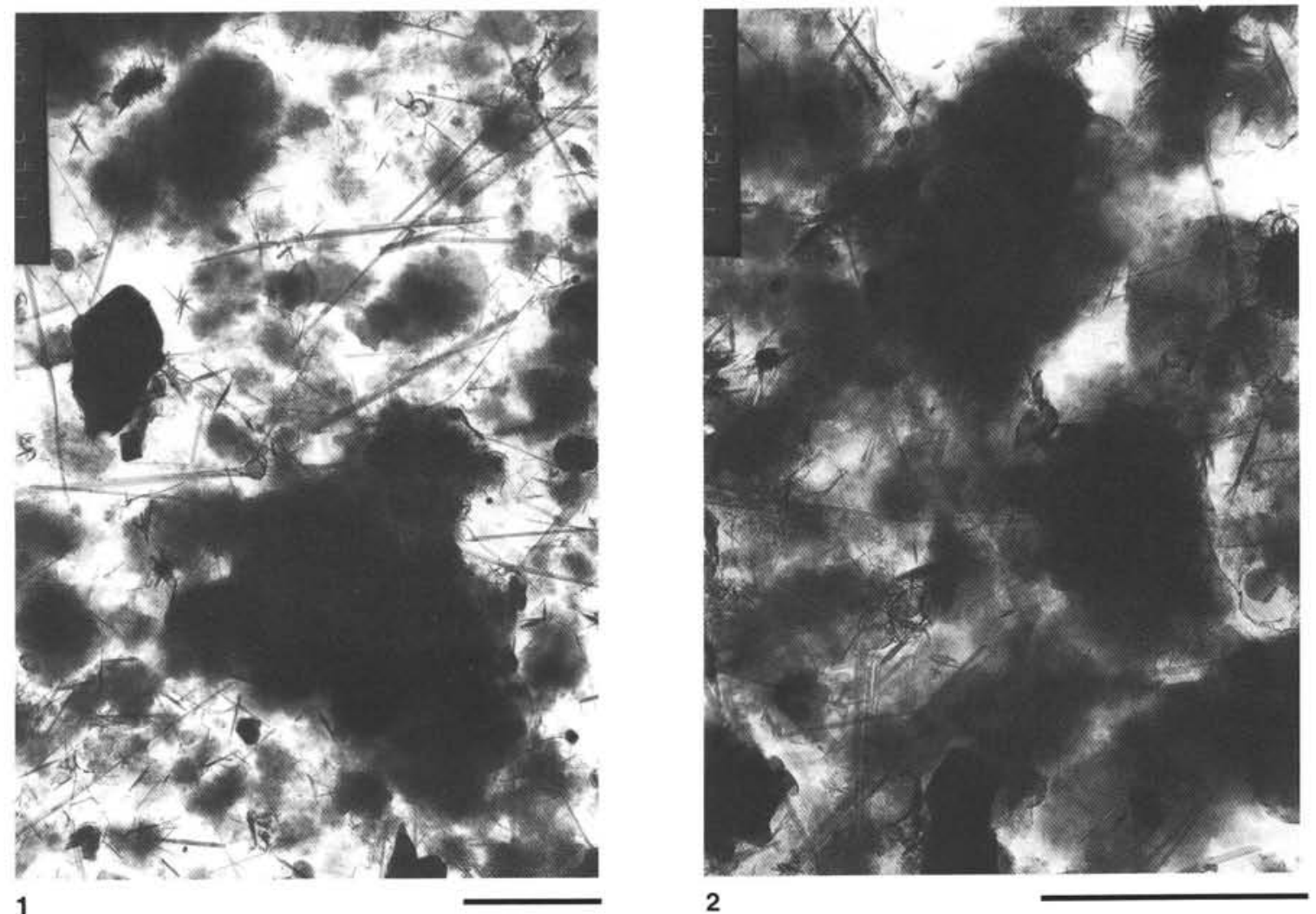

1

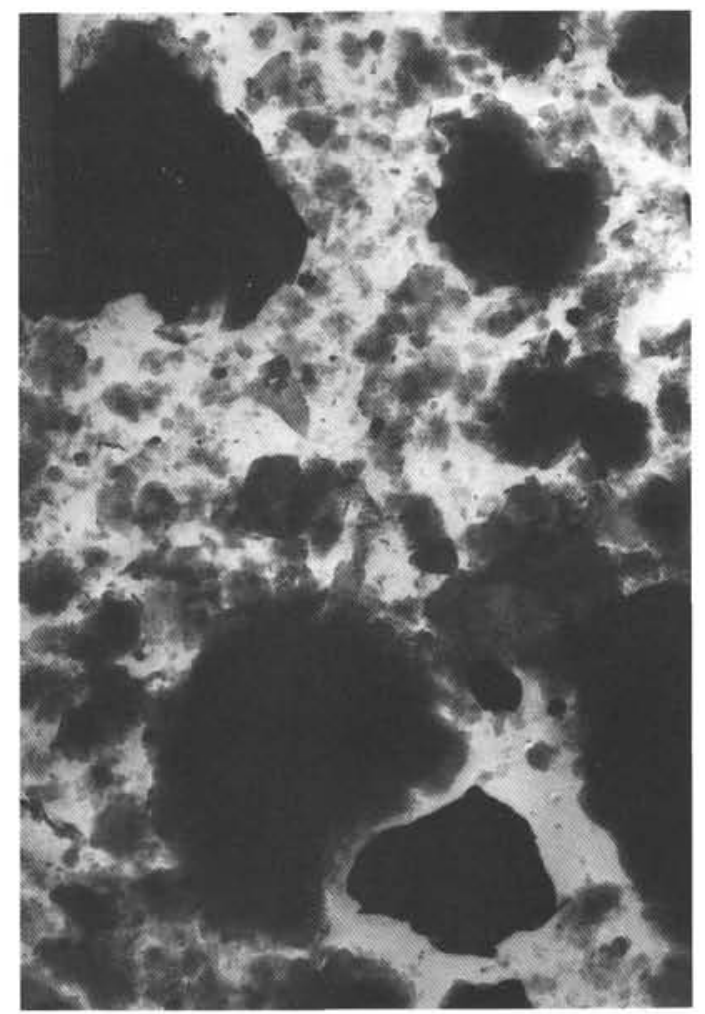

3

Plate 2. Hole 652A. Electron micrographs. Bar $=1 \mu \mathrm{m} . \quad 1,2$. Lowermost Pliocene to uppermost Messinian-Core 20R-4-141, 186.11 mbsf. Abundant smectite $(70 \%$ of clay minerals) forming fleecy sheets and associated with few well-outlined illite particles, subhexagonal kaolinite, and palygorskite isolated fibers and bundles. Presence of goethite rosettes. 3, 4. Late Messinian? Core 38R-3-145, 358.45 mbsf. Fairly abundant illite and chlorite ( $55 \%$ of clay minerals) without polygonal outlines or crystals, and accompanied by smectite, random mixed-layers, and kaolinite. Smectite and so-called mixed-layers display less fleecy outlines than overlying sediments ( $\mathrm{Pl} .2-1,-2)$. 

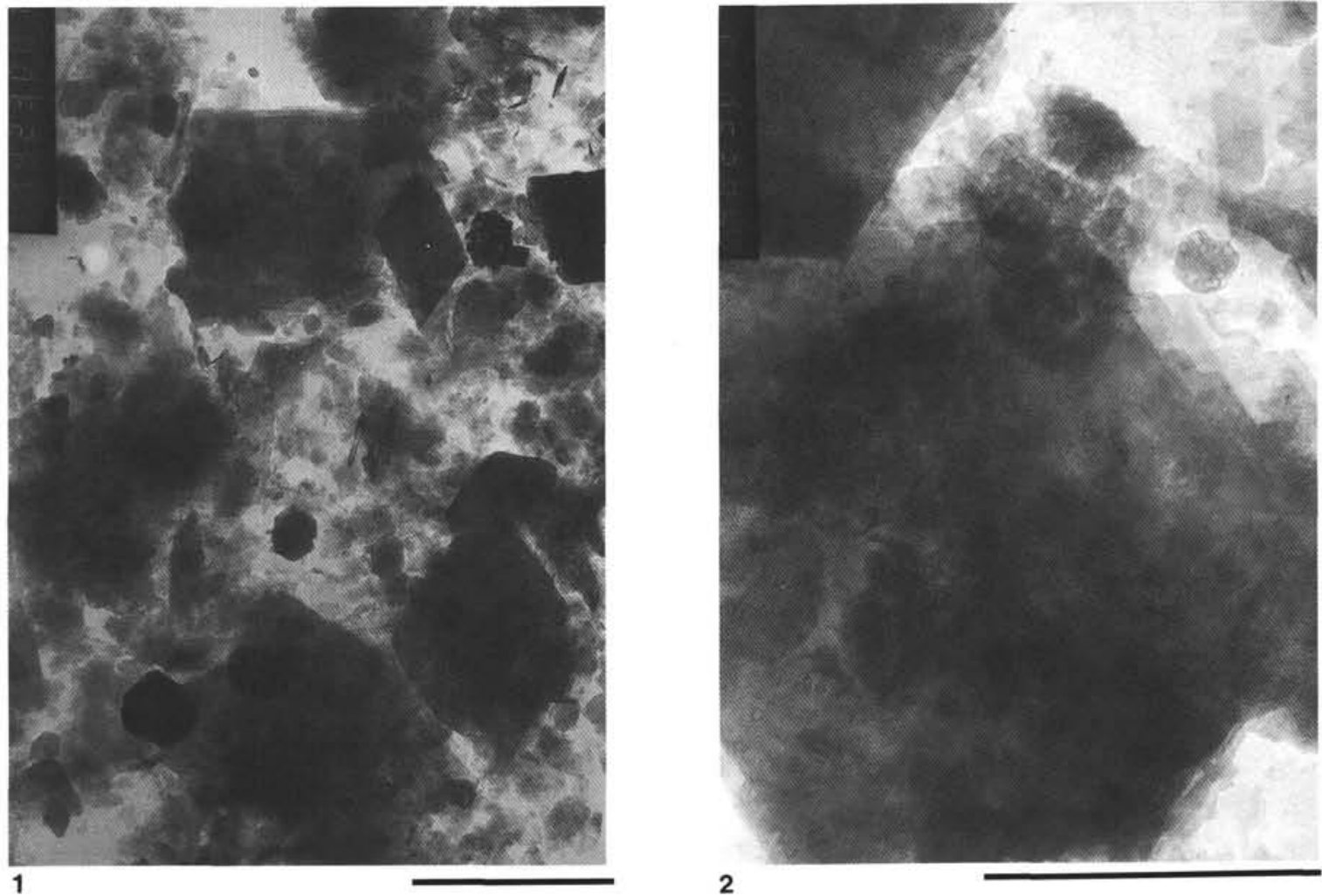

2

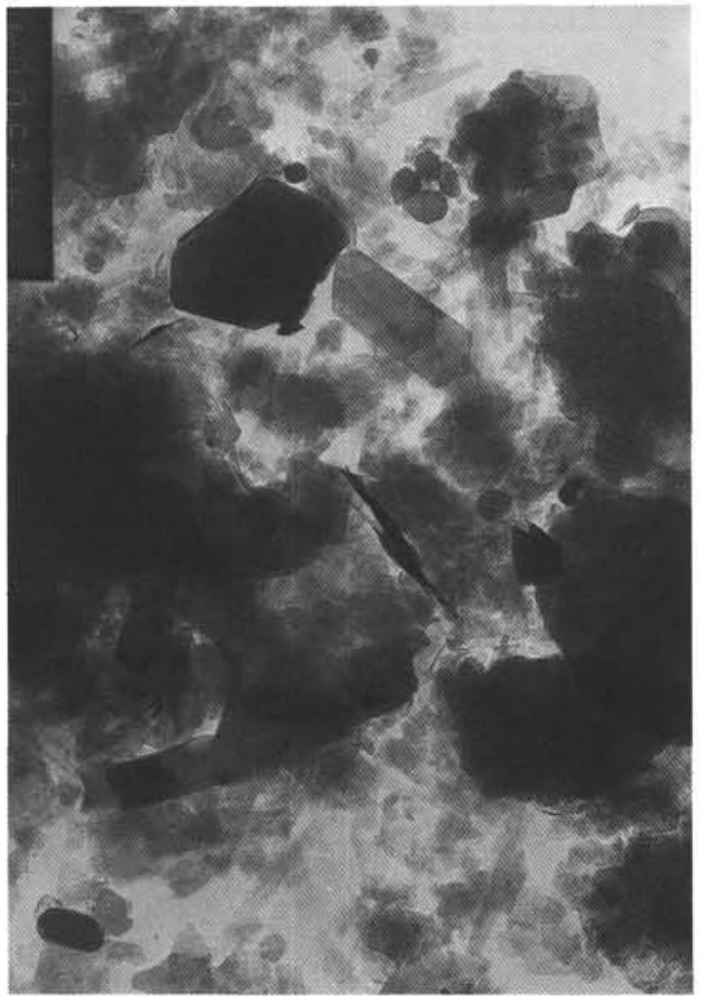

3

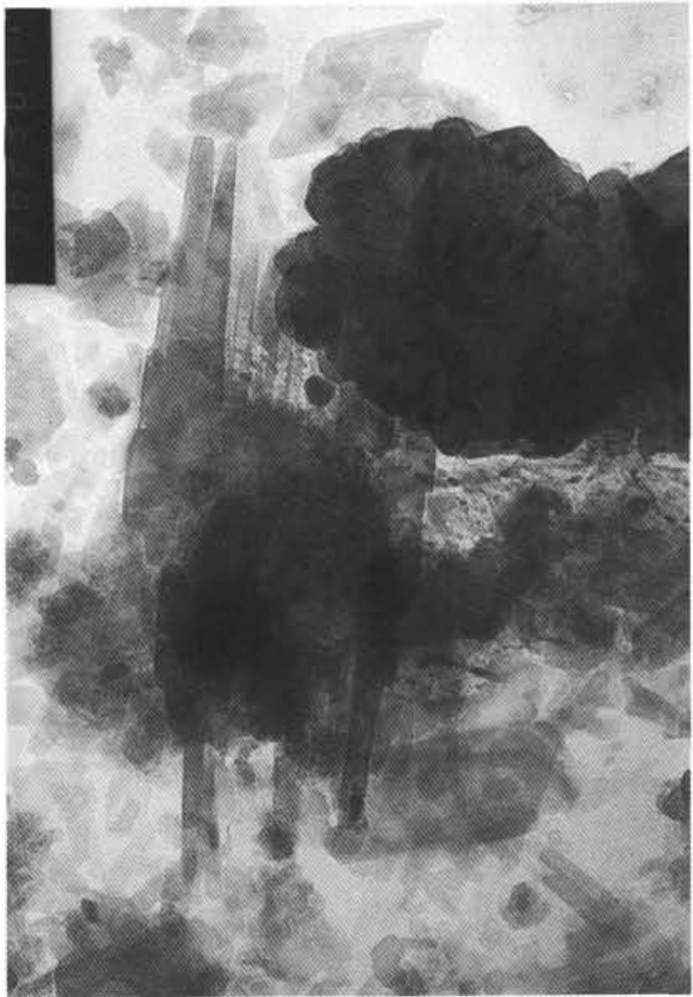

Plate 3. Hole 652A. Electron micrographs. Bar $=1 \mu \mathrm{m}$ for 1,3 , and 4 ; bar $=0.5 \mu \mathrm{m}$ for 2. 1, 2. Messinian? Core 62R-3-6, 588.27 mbsf. Polygonal, mostly hexagonal crystals of chlorite and mica-illite (35\% each), with small, electron-perforated kaolinite hexagons ( $<15 \%$ of clay). So-called illite-smectite mixed-layers form very small, well-outlined particles among large illites and chlorites. 3, 4. Messinian? Core 68R-2-55, 645.85 mbsf. Very abundant fresh hexagonal crystals of chlorite $(40 \%)$ and mica-illite $(35 \%)$, associated with little kaolinite and illite-smectite mixed-layers. Note the presence of elongated mica and/or chlorite particles. 